

\section{Sumário}

I. INTRODUÇÃO

The Datasphere and the Law: New Space, New Territories ...................................III Jean-Sylvestre Bergé e Stéphane Grumbach

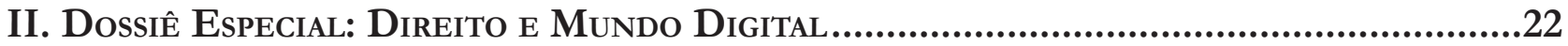

A. Criptomoedas e tecnologia blockchain ......................................................................23

Passado, presente e futuro da CRiptografia forte: DesenVolvimento tecnológico e

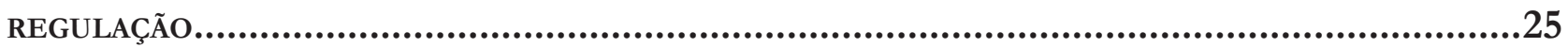
Jacqueline de Souza Abreu

Tratamento JuRídico Das CRIPTOMOEDAS: A DiNÂMiCA DOS BitCOINS E O CRIME DE LAVAGEM

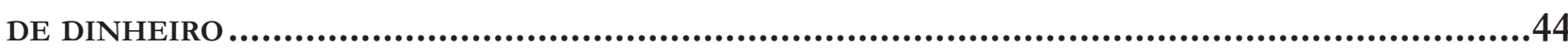
Mariana Dionísio de Andrade

TERRITÓRIO DAS CRIPTOMOEDAS: LIMITES À REGULAMENTAÇÃo ESTATAL QUANTO À CIRCULAÇÃO DE MOEDAS NO CIBERESPAÇO E POSSÍvEIS ALTERNATIVAS ..................................................61 Ranidson Gleyck Amâncio Souza

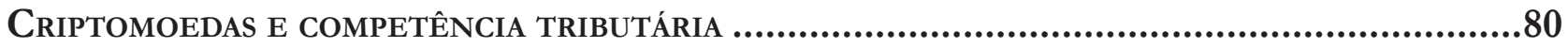
Guilherme Broto Follador

BitCoIn E A (IM)POSSIBILIDAde DE SUA PROIBIÇÃO: UMA VIOLAÇÃo À SOBERANIA Do EsTAdo?106 Rodrigo Valente Giublin Teixeira e Felipe Rangel da Silva

BlockChain e Agenda 2030

Danielle Mendes Thame Denny, Roberto Ferreira Paulo e Douglas de Castro

A reconstruÇão da JURISDição PELO ESPAÇO Digital: REDES SOCIAIS, BLOCKCHAIN E CRIPTOMOEDAS COMO PROPULSORES DA MUDANÇA.

Maria Edelvacy Pinto Marinho e Gustavo Ferreira Ribeiro

B. Proteção de dados e provedores de Internet

O tempo e O espaço. Fragmentos do marco Civil da internet: paradigmas de Proteção DA DIGNIDADE HUMANA 160 Maria Celeste Cordeiro Leite dos Santos e Marilene Araujo 
O PRojeto de Lei de PRoteção de dAdos PEssoais (PL 5276/2016) NO MUNDO do Big DATA: O FENÔMENO DA DATAVEILLANCE EM RELAÇÃo À UTILIZAÇÃO DE METADADOS E SEU IMPACTO NOS DIREITOS HUMANOS ................................................................................... 185

Elias Jacob de Menezes Neto, Jose Luis Bolzan de Morais e Tiago José de Souza Lima Bezerra

DignidADE HUMANA NA WEBESFERA GOVERNAMENTAL BRASILEIRA...................................200 Luciana Cristina Souza

CiberespaÇo E CONTEÚdo OFENSIVO GERAdo POR TERCEIROS: A PROTEÇão DOS DiREITOS DE PERSONALIDADE E A RESPONSABILIZAÇÃo CIVIL DOS PROVEDORES DE APLICAÇÃO, À LUZ DA JURisprudênCIA do Superior Tribunal de JustiçA................................................ 217 Cristiano Colombo e Eugênio Facchini Neto

A responsabilidade CIVIL pelos atos autônomos da INTEligÊnCIA ARTIFICIAL: NOTAS iniciais sobre a resolução do Parlamento Europeu ...........................................239 Thatiane Cristina Fontão Pires

Rafael Peteffi da Silva

SHARENTING, LIBERDADE DE EXPRESSÃO E PRIVACIDADE DE CRIANÇAS NO AMBIENTE DIGITAL: O PAPEL DOS PROVEDORES DE APLICAÇÃo NO CENÁRIO JURÍDICO BRASILEIRO. 256 Fernando Büscher von Teschenhausen Eberlin

THE DICHOTOMY BETWEEN SMART METERING AND THE PROTECTION OF CONSUMER'S PERSONAL DATA IN BRAZILIAN LAW..

Lucas Noura Guimarães

O CYBERBULlying E OS LIMITES DA LIBERDADE DE EXPRESSÃO 295 Janile Lima Viana, Cinthia Meneses Maia e Paulo Germano Barrozo de Albuquerque

O Supremo Tribunal Federal e o discurso de ódio nas redes sociais: exercício de DIREITO VERSUS LIMITES À LIBERDADE DE EXPRESSÃO

Carlo José Napolitano e Tatiana Stroppa

ANÁlise COMPARAdA DE ESTRATÉgIAS DE ENFRENTAMENTO A “REVENGE PORN” PELO MUNDO .... 334 Natália Neris, Juliana Pacetta Ruiz e Mariana Giorgetti Valente

USO INDEVIDO DE REDES SOCIAIS E APLICATIVOS DE MENSAGENS INSTANTÂNEAS NO AMBIENTE LABORAL 
ENSAIO SOBRE A PROMESSA JURÍDICA DO ESQUECIMENTO: UMA ANÁLISE A PARTIR DA PERSPECTIVA DO PODER SIMBÓliCo DE BOURDIEU 368 Joana Machado e Sergio Negri

UMA AGENDA PARA O DIREITO AO ESQUECIMENTO NO BRASIL. 384 Bruno de Lima Acioli e Marcos Augusto de Albuquerque Ehrhardt Júnior

NÃo AdIANTA NEM TENTAR ESQUECER: UM ESTUdo SOBRE O DIREITO AO ESQUECIMENTO...... 412 José Augusto Fontoura Costa e Geraldo Miniuci

A aplicaÇão do direito ao ESQUecimento aos agentes delitivos: uma ANÁlise aCERCA da PONDERAÇÃO ENTRE O DIREITO À IMAGEM E AS LIBERDADES DE EXPRESSÃO E DE INFORMAÇÃO437 Paulo Afonso Cavichioli Carmona e Flávia Nunes de Carvalho Cavichioli Carmona

DiREITO AO ESQUECIMENTO: NA SOCIEDADE INFORMACIONAL HÁ ESPAÇO PARA O EPÍLOGO DA MÁQUINA DE TORTURA KAFKIANA?

Alexandre Antonio Bruno da Silva e Marlea Nobre da Costa Maciel

ESQUECIMENTO, INTERNET E “PREFERÊNCIA” DA INFORMAÇÃO: POSSIBILIDADES DE APLICAÇÃO DA DOUTRINA DOS PREFERRED RIGHTS DA JURISPRUDÊNCIA NORTE-AMERICANA AO CASO BRASILEIRO 484

Maria Vital da Rocha, Isaac Rodrigues Cunha e Karin de Fátima Rodrigues Oliveira

D. Propriedade intelectual 510

Direitos AUtorais E MÚSICA: TECNOLOGIA, DiREITO E REGUlaÇão Marcia Carla Pereira Ribeiro, Cinthia Obladen de Almendra Freitas e Rubia Carneiro Neves

Direito AUTORAL NA CIBERCUlTURA: UMA ANÁLISE Do ACESSO AOS BENS IMATERIAIS A PARTIR DAS LICENÇAS CREATIVE COMMONS 4.0.

Gabriela Maia Rebouças e Fernanda Oliveira Santos

E. Políticas públicas e novas tecnologias.

SALTO DIGITAL NAS POLÍTICAS PÚBLICAS: OPORTUNIDADES E DESAFIOS .561 Marcelo D. Varella, Clarice G. Oliveira e Frederico Moesch

Fostering E-gOVERnMENT IN BRAZIL: A CASE STUdY OF DIGITAL CERTIFICATION ADOPTION.585 Lamartine Vieira Braga

DEMOCRATIZAÇÃo NA ERA Digital: DESAFIOS PARA UM DiÁlOgo CONSCIENTE E IGUALITÁRIO.602 Raquel Cavalcanti Ramos Machado e Laura Nathalie Hernandez Rivera 
REDES SOCIAIS E CROWDSOURCING CONSTITUCIONAL: A INFLUÊNCIA DA CIBERDEMOCRACIA SOBRE A GÊNESE E A INTERPRETAÇÃO DE NORMAS CONSTITUCIONAIS ...................................... 618 Igor Ajouz

MARCo CIVIL DA INTERNET E POLÍTICA PÚbliCA DE TRANSPARÊNCIA: UMA ANÁLISE DA E-DEMOCRACIA E DO COMPLIANCE PÚBLICO.

Juliana Costa Zaganelli e Wallace Vieira de Miranda

Políticas públicas bRasileiras de COMPUTAÇÃo EM NUVEM: ANÁLISE DOCUMENTAL dos RELATÓRIOS DO GLOBAL CLOUD COMPUTING SCORECARD

Lucas dos Santos Costa e Marcos Fernando Machado de Medeiros

O uso monopolista do Big Data POR EMpresas de aplicativos: políticas públicas para UM DESENVOLVIMENTO SUSTENTÁVEL EM CIDADES INTELIGENTES EM UM CENÁRIO DE ECONOMIA CRIATIVA E DE LIVRE CONCORRÊNCIA...................................................................6 672 José Antonio Remedio e Marcelo Rodrigues da Silva

1. Introdução

2. A urbanização das cidades e a sociedade em rede: economia criativa, colaborativa e compartilhada como formas de concretização de funções sociais da cidade.

4. Concorrência e Big Data Business relevantes às Smart Cities: estudo de caso envolvendo a aquisição do Waze pelo Google

5. Considerações finais

Referências

III. OUTROS TEMAS

COMO SALVAR O SISTEMA DE REPERCUSSÃo GERAL: TRANSPARÊNCIA, EFICIÊNCIA E REALISMO NA escolha do Que o Supremo Tribunal Federal vai Julgar.. .696 Luís Roberto Barroso e Frederico Montedonio Rego

Precariedade do sistema penitenciário brasileiro como base temática para a proibição OU LEGALIZAÇÃO DAS DROGAS. 715

Lilian Rose Lemos Rocha e José Eduardo Cardozo

A terceira margem do constitucionalismo republicano: uma Crítica A Frank Michelman. .732

Daniel Barcelos Vargas

Medida PRovisória E CONTROLE DE CONSTITUCIONALIDADE: RELEVÂNCIA, URGÊNCIA E PERTINÊNCIA TEMÁTICA

Clarice G. Oliveira e José Levi Mello do Amaral Júnior 
ОвJETO E CONCEITO DO DIREITO ADMINISTRATIVO: REVISÃo CRÍTICA...................................765 Carlos Bastide Horbach

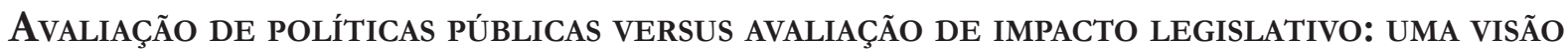
DICOTÔMICA DE UM FENÔMENO SINGULAR

Aparecida de Moura Andrade e Héctor Valverde Santana

LOS AVATARES DEL INTERÉS DEFINIDO EN TÉRMINOS DE PODER EN LA FORMULACIÓN DE LAS POLÍTICAS PÚBLICAS

Louis Valentin Mballa

CONSEQUENCIALISMO JUdicial NA MODUlaÇão DE EFEITOS DAS DECISÕES DECLARATÓRIAS DE INCONSTITUCIONALIDADE NOS JULGAMENTOS DE DIREITO TRIBUTÁRIO 819

Fernando Leal e Daniela Gueiros Dias

JudicializaÇão da SAÚde: A dignidade da PESSOA HuMana E A ATUAÇão do Supremo Tribunal Federal no caso dos medicamentos de alto custo

Fabricio Veiga Costa, Ivan Dias da Motta e Dalvaney Aparecida de Araújo 


\title{
Consequencialismo judicial na modulação de efeitos das decisões declaratórias de inconstitucionalidade nos julgamentos de direito tributário*
}

\author{
Judicial consequentialism and the \\ prospective effect of constitutional rullings \\ on taxation matters
}

\author{
Fernando Leal** \\ Daniela Gueiros Dias***
}

\section{Resumo}

O presente trabalho analisa o uso de argumentos consequencialistas na jurisprudência do Supremo Tribunal Federal para a modulação dos efeitos temporais da decisão declaratória de inconstitucionalidade em julgamentos de direito tributário. No estudo, analisa-se o apelo a consequências na solução de casos concretos e se identificam potenciais problemas relativos à adoção desse tipo de argumento pelos ministros no STF.

Palavras-chave: Consequencialismo. Argumentação Jurídica. Racionalidade. STF.

\begin{abstract}
The present work analyses the appeal to consequences in the rulings of the Brazilian Supreme Court when it establishes a prospective effect in cases related to taxation matters. In this paper, we explore empirically the use of consequentialist reasoning in the solution of concrete cases and identify potential problems related to the adoption of this kind of arguments by the Justices of the Brazilian Supreme Court.
\end{abstract}

Keywords: Consequentialism. Legal Reasoning. Rationality. Brazilian Supreme Court.

* Recebido em 15/08/2017

Aprovado em 15/09/2017

** Doutor em Direito pela Christian-Albrechts-Universität zu Kiel. Doutor e Mestre em Direito Público pela Universidade do Estado do Rio de Janeiro (UERJ). Professor e coordenador adjunto do mestrado em Direito da Regulação da FGV Direito Rio. Email: farleal@ hotmail.com

*** Mestranda em Direito Tributário (USP). Advogada. Email: dani_gueiros@hotmail.com

\section{INTRODUÇÃO}

O uso de argumentos consequencialistas pelos ministros do Supremo Tribunal Federal (STF) tem se tornado cada vez mais frequente ${ }^{1}{ }^{2}$ em um

1 PISCITELLI, Tathiane dos Santos. Argumentando pelas consequências no direito tributário. São Paulo: Noeses, 2011 p. 1-10;235-269.

2 Segundo Mariana Pargendler e Bruno Meyerhof Salama, "o Poder Judiciário de muitos países, incluindo-se o Brasil, está envolvido até o pescoço com a formulação de políticas 
cenário de "expansão da autoridade do Supremo em detrimento dos demais poderes"3.

A título meramente exemplificativo, no RE 134.509, no qual se discutiu a incidência do Imposto sobre Propriedade de Veículos Automotores em relação a embarcações e aeronaves, o Plenário do STF declarou que estes não configuram fato gerador do tributo. A questão para a análise dos ministros poderia ser colocada como um problema jurídico tradicional relacionado à abrangência ou não da regra constitucional, que trata de "veículos automotores", ao caso concreto ${ }^{4}$. No entanto, considerações consequencialistas parecem ter exercido um peso decisivo sobre a decisão final, de forma que a solução do caso não se restringiu à questão da mera incidência normativa. É o que se depreende do voto do Ministro Francisco Rezek:

[...] se se fizer a análise etimológica da expressão "veículos automotores", como fez o autor citado nos autos, é sempre possível concluir que se pode enquadrar no conceito de veículo automotor o navio e a aeronave. Pode ser enquadrada também qualquer criatura do reino animal, veículo que é porque capaz de transportar coisas, e automotor porque independente de qualquer tração externa à sua própria estrutura física. [...]

O que se espera do doutrinador, quando escreve sobre direito tributário, não é que nos diga aquilo que pensa sobre o significado das palavras. [...]

Penso no que seriam as consequências de se abonar a constitucionalidade dessa exação. Penso em como se deveriam alterar normas relacionadas com registros e cadastros. Penso no IPVA, que o constituinte manda ser arrecadado por Estados e repartido depois com o município onde está licenciado cada veículo. Penso em como se afetarão navios e aviões aos municípios...

Se isso devesse ser feito, para dar alguma valia operacional à pretensão tributária de alguns Estados, imagino as consequências. [... $]^{5}$

Como se constata, o ministro Francisco Rezek acreditava que a determinação da hipótese de incidência do IPVA exclusivamente com base na conceituação de "veículos automotores" poderia levar a entendimentos absurdos, já que, em última análise, “[d]os animais mais lentos, [...], aos mais velozes; dos mais robustos, [...], aos mais frágeis, todos nós incluiríamos no conceito de veículo automotor se ele devesse ser compreendido semanticamente".

Por essa razão, há necessidade de que, segundo o ministro, a constitucionalidade da exação fosse analisada a partir das consequências que a decisão poderia gerar no mundo real. A dificuldade de criação de registros nos Estados e Municípios com a finalidade de afetar aeronaves e embarcações às suas jurisdições, bem como o conflito que surgiria entre entes federados "desejosos, de algum modo, de aumentar sua receita mediante a aplicação de tarifas reduzidas e outras coisas mais" seriam, aos olhos do ministro Francisco Rezek, consequências negativas que, como tais, deveriam ser evitadas. Assim, a solução mais adequada ao problema seria rechaçar a incidência do IPVA sobre embarcações e aeronaves.

A linha argumentativa do ministro Francisco Rezek permite perceber que os argumentos consequencialistas desempenharam um papel central em sua tomada de decisão, inclusive maior do que própria interpretação semântica da regra de incidência tributária. O problema parece residir no fato de que, apesar de intuitivas, as consequências elencadas pelo ministro não são sustentadas por nenhum dado empírico que permita aferir a probabilidade de elas de fato se materializarem. Generalizada, essa prática pode deixar os

públicas. E assim - quer gostem, quer não gostem, quer o façam aberta ou veladamente - seus integrantes estão iressistivelmente impingidos a pensar seriamente sobre relações de adequação entre meios jurídicos e fins normativos, relações essas que não podem ser obtidas somente com a filosofia, a lógica, a filologia ou a gramática. Como se vê, trata-se de um Poder Judiciário, ousamos dizer, ávido por estudos que articulem a interpretação do texto da lei com suas prováveis repercussões práticas." In PARGENDLER, Mariana; SALAMA, Bruno Meyerhof. Direito e Consequência no Brasil: em busca de um discurso sobre o método. Revista de Direito Administrativo (RDA), Rio de Janeiro, v. 262, p. 127, jan./abr. 2013.

3 VIEIRA, Oscar Vilhena. Supremocracia. Revista Direito GV, São Paulo, n. 8, p. 441-464, jul./dez. 2008.

4 Na hipótese, o caso poderia ser considerado a expressão de um problema de textura aberta da linguagem. V. a respeito HART, H. L. A. The concept of law. 2. ed. Oxford: Oxford University Press, 1994. p. 126.

5 STF. Recurso Extraordiário n. 134509. Relator: Min. Marco Aurélio. Relator. p/ acórdão: Min. Sepúlveda Pertence, Tribunal Pleno, 29 de maio de 2002. Diário da Justiça, 13 set. 2002. 
processos de tomada de decisão dependentes excessivamente das especulações dos juízes sobre os efeitos de suas possíveis decisões.

Assim, se é verdade que em alguns julgamentos na seara tributária, tal como no exemplo acima, os ministros não apenas pensam nos efeitos, mas de fato usam argumentos consequencialistas para justificar as suas decisões, então faz sentido perquirir se é "possível controlar normativamente o futuro em sua conexão com o passado e o presente" num cenário de incerteza e imprevisibilidade, no qual as capacidades epistêmicas dos ministros para se engajar nesse tipo de argumento não são óbvias.

Essas incertezas levantam uma série de questões a respeito da ampla utilização de argumentos consequencialistas em processos de tomada de decisão jurídica, pois a impossibilidade de prever o futuro poderia vincular aos juízos prospectivos típicos da argumentação consequencialista altas margens de discricionariedade judicial.

Isso porque, de um lado, não é desejável que os ministros justifiquem suas decisões com base exclusivamente nas consequências que elas podem gerar, haja vista a necessidade de que as razões apresentadas encontrem suporte no direito, e não nas intuições ou valorações pessoais do tomador de decisão, impedindo, assim, decisões arbitrárias?

Em sentido oposto, porém, é igualmente indesejável que nenhuma das possíveis consequências da decisão sejam levadas em consideração em julgamentos tributários, já que decisões judiciais apresentam uma pretensão de universalização a partir da solução apresentada no caso concreto ${ }^{8}{ }^{9}$, o que exige que o aplicador pense, seriamente, na consequência de suas decisões ante à possibilidade de sua universalização ${ }^{10}$. Este é um reclame isonômico, na medida em que casos semelhantes devem ser tratados de forma semelhante ${ }^{11 \_}{ }^{12}$.

6 LUHMANN, Niklas. Sistema Jurídico y Dogmática Jurídica. Madrid: Centro de Estudios Constitucionales, 1983. p. 73.

7 ÁVILA, Humberto. A justificação das decisões judiciais. In: Seminário Teoria da Decisão Judicial, 23, 24 e 25 de abril de 2014 , Brasília, DF. Conselho da Justiça Federal, Centro de Estudos Judiciários, Coordenação Científica: Ricardo Villas-Bôas Cueva. Brasília: CJF, 2014. Disponível em: <http://www.cjf.jus.br/CEJ-Coedi/serie-cadernos/serie-caderno-30 >. Acesso em: 27 set. 2015.

8 A pretensão de universalização, além de ser um reclame isonômico, decorre do próprio ordenamento jurídico brasileiro o qual, em diversos dispositivos, procura uniformizar a aplicação do direito. A título meramente exemplificativo, em nível constitucional, a Constituição Federal de 1988 determina que "[a]s decisões definitivas de mérito, proferidas pelo Supremo Tribunal Federal, nas ações diretas de inconstitucionalidade e nas ações declaratórias de constitucionalidade produzirão eficácia contra todos e efeito vinculante, relativamente aos demais órgãos do Poder Judiciário e à administração pública direta e indireta, nas esferas federal, estadual e municipal" (art. 102, $\$ 2^{\circ}$ ). Igualmente, no controle difuso, tem-se a resolução do Senado visando à suspensão da execução, no todo ou em parte, de lei declarada inconstitucional por decisão definitiva do Supremo Tribunal Federal (art. 52, X). Já no plano infraconstitucional, a pretensão de universalização das decisões judiciais é notória em diversos institutos do Novo Código de Processo Civil, como o julgamento mediante a sistemática dos recursos repetitivos (art. 979, §3º da Lei 13.105/2015) e o incidente de resolução de demandas repetitivas (art. 976 e ss., da Lei 13.105/2015).

9 Segundo Neil MacCormick, ao argumentar pelas consequências, somente aquelas genéricas e não específicas do caso concreto são relevantes, já que o processo de justificação se preocupa em demonstrar o motivo pelo qual uma decisão é preferível às demais. No original: " because the justification proceeds by way of showing why such a decision ought to go one way rather than the other, the relevant consequences are those of generic ruling involved in deciding one way or the other, not just the specific effects of the specific decision on the individual parties. MACCORMICK, Neil. Legal Reasoning and Legal Theory: Clarendon Law Series. Oxford: Oxford University Press, 1978. p. 150.

10 MACCORMICK, Neil. Rhethoric and the Rule of Law: A Theory of Legal Reasoning (Law, State and Practical Reason). Oxford: Oxford University Press, 2005. p. 102.

11 Lewis Sargentich defende que o Direito funda-se em três premissas básicas que se revelam, concomitantemente, como aspirações a serem alcançadas pelo Direito. A primeira delas é a noção de legal entitlement, a partir da qual a posição das pessoas na sociedade depende das leis e não da discricionariedade de um soberano ou indivíduo (non sub homine, sed sub Deo et lege). A segunda aspiração é a de justiça formal, de onde se depreende que casos semelhantes devem ser tratados de forma semelhante. Em existindo justiça no sentido formal, os indivíduos são capazes de determinar qual o padrão de comportamento a ser seguido. O oposto da justiça formal, para o professor, é a compreensão de um caso de maneira isolada, sem que se atente para o fato de que ele compõe o ordenamento jurídico no qual se insere. Por fim, a terceira aspiração do direito é a racionalidade jurídica (legal rationality ou law like rationality no original), decorrência lógica das demais premissas. A ideia é que pessoas racionalmente capazes podem entender o significado das leis e se comportar de acordo com elas. Resoluções racionais seriam alicerces para a concretização de legal entitlement. Igualmente, racionalidade é entendida por Sargentich em sentido amplo, abarcando a noção de coerência das normas do ordenamento jurídico, e garantindo-se, dessa forma, que a aspiração de justiça formal seja concretizada (SARGENTICH, Lewis. Jurisprudence: legal ideals. Harvard Law School, 15 set. 2015. Notas de aula.).

12 Um ordenamento jurídico muito complexo, tal como seria de se imaginar quando se permite a ampla utilização de argumentos 
Dessa forma, os dois extremos acima apresentados devem ser rechaçados, já que o primeiro exclui a possibilidade de justificativas racionais baseadas em considerações consequencialistas ante a existência de incertezas relativas ao futuro e à imprevisibilidade absoluta das cadeias de consequências, enquanto o segundo ignora não somente que a qualidade das decisões judiciais pode depender das consequências que o aplicador pretende ver concretizadas no mundo real como também da necessidade de que ele aja com prudência e responsabilidade ao decidir ${ }^{13}$. Ademais, se os ministros devem conquistar a confiança dos indivíduos constantemente e isto é feito por meio das justificativas que apresentam nas suas decisões ${ }^{14}$, talvez faça sentido exigir que as razões apresentadas considerem, seriamente, as diversas consequências que provavelmente advirão de cada alternativa decisória.

Nesse contexto, o presente trabalho tem por objeto a análise crítica do uso do consequencialismo judicial para a modulação dos efeitos das decisões declaratórias de inconstitucionalidade, nos termos do art. 27, da Lei 9.868/1999 ${ }^{15}$, pelos ministros do Supremo Tribunal Federal no julgamento de questões envolvendo Direito Tributário. Inicialmente, convém deixar claro que o trabalho não tem por objetivo defender o uso de argumentos consequencialistas como panaceia geral para a solução de conflitos nesta seara do Direito. A ideia é analisar como argumentos consequencialistas são operacionalizados no Supremo para, a partir daí, permitir críticas mais profundas sobre a aplicação generalizada de raciocínios consequencialistas no direito.

Nesse momento, porém, o presente trabalho se centra no levantamento de dados sobre o processo de justificação de decisões no STF, no que se revela o seu propósito prioritariamente empírico. Tendo esse objetivo em vista, busca-se responder às seguintes perguntas de pesquisa: (i) os ministros, quando evocam a modulação de efeitos temporais de decisões que envolvem a superação de discussões tributárias, utilizam argumentos consequencialistas? Em caso positivo, (ii) as prognoses inerentes à argumentação com base em consequências, quando realizadas pelos ministros do STF, são acompanhados de documentos, estudos ou dados capazes de lhes servir de suporte? As hipóteses são: (i) os ministros utilizam argumentos consequencialistas e (ii) a maior parte dos júzos sobre o futuro por eles efetuados não são acompanhados de documentos, estudos ou dados capazes de lhes servir de suporte. Uma vez confirmada a hipótese (ii), apontam-se alguns problemas relacionados à utilização de argumentos consequencialistas na jurisprudência do Supremo Tribunal Federal e se argumenta que possíveis déficits epistêmicos podem comprometer o engajamento dos ministros nesse tipo de argumento.

\section{Metodologia}

Em que pese a alta demanda pelo curso de Direito no país, a pesquisa jurídica, quando comparada às pesquisas realizadas em outras áreas do saber (medicina, economia e engenharia, e.g.), é atrasada ${ }^{16}$. Basta destacar, nesse sentido, que a existência de 1.240 faculdades de Direito no território nacional, ainda em 2015,

consequencialistas, poderia acabar influenciando no tratamento antiisonômico dos cidadãos. Segundo Michael Graetz e Deborah Schenk, "[c]omplexity is inequitable because taxpayers with equal ability to pay may have different tax burdens because of their unequal abilities to understand or manipulate tax rules" (GRAETZ, Michael J.; SCHENK, Deborah. Federal Income Taxation: principles and Policies. 7. ed. St. Paul: Foundation Press, 2013. p. 29).

13 MACCORMICK, Neil. On Legal Decisions and their Consequences: from Dewey to Dworkin. New York University Law Review, v. 58, n. 2, p. 239-240, maio 1983.

14 AARNIO, Aulis. Introduction. In: PECZENIK, Aleksander. On Law and Reason. Preface by Jaap C. Hage. Law and Pbilosophy Library, Sweden: Springer, v. 8, p. 4, 2008.

15 A modulação temporal também é possível nos termos do art. 11, da Lei 9.882/1999 (lei que dispõe sobre o processo e julgamento da argüição de descumprimento de preceito fundamental, nos termos do $\int 1^{\circ}$ do art. 102 da Constituição Federal). No entanto, na pesquisa realizada, não se encontrou nenhum caso de modulação em julgamento de direito tributário em sede de ADPF, razão pela qual ao longo deste Trabalho de Conclusão de Curso, optou-se por trabalhar somente com a hipótese do art. 27, da Lei 9868/1999.

16 ADEODATO. João Maurício. Bases para uma metodologia da pesquisa em direito. Revista CEJ, Brasília: Conselho da Justiça Federal, Centro de Estudos Judiciários, v. 7, p. 143-150, 1998. 
num quadro em que o restante do mundo totalizava 1.100 universidades ${ }^{17}$, é acompanhada de uma produção jurídica que às vezes recorre às técnicas de "manualismo" e "reverencialismo", reproduzindo, de maneira acrítica, o conteúdo e a estrutura de manuais ao mesmo tempo que argumentos de autoridade parecem encerrar qualquer controvérsia cuja solução demande um estudo mais aprofundado ${ }^{18}$.

No cenário acima descrito, em que a maior parte da comunidade jurídica brasileira parece compreender a pesquisa jurídica como um "levantamento bibliográfico" e, quando muito, uma "análise crítica com confronto de teses, com o predomínio de pesquisas teóricas e dogmáticas" "19, a abordagem empírica tem sido preterida. A questão pode se revelar como um paradoxo se, na linha das críticas tecidas por João Maurício Adeodato, "além da ignorância sobre como pesquisar e como apresentar os resultados de suas pesquisas, os juristas estão em geral tão envolvidos com problemas práticos do dia-a-dia que não têm tempo para estudos mais aprofundados" 20 . O paradoxo consiste, precisamente, no fato de que a má qualidade da produção jurídica é atribuída, dentre outras coisas, ao envolvimento exacerbado com problemas do cotidiano e, no entanto, poucos são os trabalhos de Direito que se preocupam com questões empíricas.

Buscando contribuir, ainda que de forma reduzida, para a alteração desse quadro, o presente texto adota uma metodologia empírica para a discussão de problemas teóricos.

O objeto do presente trabalho são todos os julgamentos de Direito Tributário, realizados entre o período de novembro de 1999 a outubro de 2015, no Supremo Tribunal Federal, nos quais se discutiu a modulação de efeitos da declaração de inconstitucionalidade com fundamento no art. 27, da Lei 9.868/1999.

A delimitação do objeto parte da premissa de que houve uma mudança relativamente recente na forma de se estudar o Direito Tributário no país. Se, antes se defendia que esse ramo deveria ser analisado de maneira isolada, livre da "contaminação entre princípios e conceitos jurídicos e princípios e conceitos pré-jurídicos (econômicos, financeiros, políticos, sociais etc.)" "21, hoje é possível verificar uma tendência de compreender essa seara do Direito em sua conexão com as demais áreas do saber, como, por exemplo, a economia e a política ${ }^{22}$. Dessa forma, imagina-se que o Direito Tributário seja campo fértil para o proliferamento de argumentos consequencialistas, uma vez que esses trazem para dentro do mundo jurídico a preocupação com os efeitos de uma determinada decisão sobre o mundo prático.

A escolha por analisar especificamente o uso de argumentos consequencialistas na modulação de efeitos da declaração da inconstitucionalidade com fundamento no art. 27, da Lei 9.868/1999 justifica-se (i) pela peculiaridade desse instituto, uma vez que ele configura uma "contraordem" ao Direito, na medida em que, a despeito da declaração de invalidade de uma norma jurídica, mantêm-se os atos que lhe são contrários ${ }^{23} \mathrm{e}$ (ii) na necessidade de que, ao modular, os ministros do Supremo analisem os "efeitos negativos da modificação de situações jurídicas já consolidadas no âmbito social"24, o que poderia significar uma argumentação mais preocupada com consequências. De fato, a dicção do artigo 27 leva a crer que a aplicação adequada do dispositivo exija um raciocínio prospectivo. Isso porque a modulação só se justifica se a declaração de invalidade da lei ou ato normativo no caso promover um estado de coisas que possa ser avaliado negativamente

17 Esses dados foram divulgados pela Ordem dos Advogados do Brasil. Disponível em: <http://www.oab.org.br/noticia/20734/ brasil-sozinho-tem-mais-faculdades-de-direito-que-todos-os-pai ses>. Acesso em: 4 nov. 2015.

18 OLIVEIRA, Luciano. Não fale do Código de Hamurábi! Anuário dos Cursos de Pós-Graduação em Direito (UFPE), v. 13, p. 299-330, 2003. Disponível em: < https://www.uniceub.br/media /180293/Texto_IX.pdf>. Acesso em: 4 nov. 2015.

19 OLIVEIRA, Fabiana Luci de (Org). Justiça em foco: estudos empíricos. Rio de Janeiro: Editora FGV, 2012. p. 7.

20 ADEODATO. João Maurício. Bases para uma metodologia da pesquisa em direito. Revista CEJ, Brasília: Conselho da Justiça Federal, Centro de Estudos Judiciários, v. 7, p. 143, 1998.

21 Segundo Becker, "[e]ssa contaminação prostitui a atitude mental jurídica" e é responsável pela introdução de incerteza e contradição no mundo jurídico. BECKER, Alfredo Augusto. Teoria Geral do Direito Tributário. 4. ed. São Paulo: Noeses, 2007. p. 42.

22 A título meramente exemplificativo, Luís Eduardo Schoueri afirma que "[s]endo a tributação um fenômeno histórico, político, econômico e social, as contribuições oferecidas por essas aproximações não podem ser desprezadas na busca da construção de um sentido ao todo tributário." SCHOUERI, Luís Eduardo. Direito Tributário. 4. ed. São Paulo: Saraiva, 2014. p. 17.

23 ÁVILA, Humberto. Teoria da Segurança Jurídica. 3. ed. São Paulo: Malheiros, 2014. p. 515.

24 CARVAlHO, Paulo de Barros. Direito tributário: linguagem e método. 4. ed. São Paulo: Noeses, 2011. p. 317. 
com base na segurança jurídica ou excepcional interesse social.

A delimitação temporal se justifica pelo fato de que a Lei 9.868/1999, que confere ao STF a prerrogativa de restringir os efeitos da declaração de inconstitucionalidade ou decidir que ela só tenha eficácia a partir do trânsito em julgado ou de algum outro momento ${ }^{25}$ a ser fixado, somente passou a vigorar no dia 10 de novembro de 1999. O marco final em outubro de $2015^{26}$ foi um corte arbitrário cuja finalidade era impedir a consideração de novas decisões uma vez que a análise descritiva estivesse concluída.

A delimitação quanto ao que constitui “julgamentos de direito tributário nos quais se discutiu a modulação de efeitos da declaração de inconstitucionalidade com fundamento no art. 27, da Lei 9.868/1999" foi feita com base no próprio sítio do STF (http://www.stf.jus.br/) ${ }^{27}$.

Os termos "tributário modulação", "tributação modulação" e "tributo modulação" foram os parâmetros de busca inseridos no campo "pesquisa livre" na página de pesquisa de jurisprudência do sítio do STF. Além disso, os termos "tributário", "tributação" e "tributo" foram inseridos, individualmente, no campo "pesquisa livre", ao mesmo tempo que "lei ordinária" foi selecionada no campo legislação, "9868" inserido em número, e "27" inserido em artigo. O intuito era assegurar que o maior número possível de casos seria analisado.

Em relação à primeira busca (“tributário modulação"), obteve-se um total de 95 acórdãos, todos válidos para análise. Em relação à segunda busca ("tributação modulação"), 8 acórdãos foram encontrados, dos quais 2 não constavam no grupo anteriormente obtido. Em relação á terceira busca ("tributo modulação"), dos 33 acórdãos e 1 repercussão geral, 28 acórdãos já haviam sido obtidos nas buscas anteriores, de forma que 5 acórdãos e 1 repercussão geral foram adicionados. Da quarta busca (“tributário lei 9868 art 27”) resultaram 35 acórdãos, dos quais 12 eram inéditos. Um acórdão foi excluído porque não tratava de assunto tributário ${ }^{28}$ e os 11 restantes foram adicionados à base de dados. Da quinta busca (“tributo lei 9868 art 27”), 17 acórdãos e 1 repercussão geral foram encontrados, dos quais somente 2 acórdãos ainda não haviam sido inseridos na base de dados. Por fim, da sexta busca (“tributação lei 9868 art 27”), 3 acórdãos foram encontrados, mas todos já haviam sido obtidos nas buscas anteriores.

A base de dados é composta por 116 acórdãos (115 acórdãos e 1 repercussão geral). Em relação ao total, 31 julgamentos foram feitos pelo Órgão Pleno do STF, 35 pela Primeira Turma e 50 pela Segunda Turma. Como por expressa disposição legal somente é possível a modulação com o quórum de dois terços dos

25 Antes da entrada em vigor da Lei no 9.868/1999, o Supremo Tribunal Federal já modulava os efeitos das declarações de inconstitucionalidade. A título meramente exemplificativo, tem-se o RE 122.202 de relatoria do Ministro Francisco Rezek, julgado em 10/08/1993. Confira-se a ementa: RECURSO EXTRAORDINÁRIO. EFEITOS DA DECLARAÇÃO DE INCONSTITUCIONALIDADE EM TESE PELO SUPREMO TRIBUNAL FEDERAL. ALEGAÇÃO DE DIREITO ADQUIRIDO. Acórdão que prestigiou lei estadual a revelia da declaração de inconstitucionalidade desta ultima pelo Supremo. Subsistencia de pagamento de gratificação mesmo após a decisão erga omnes da corte. Jurisprudência do STF no sentido de que a retribuição declarada inconstitucional não é de ser devolvida no período de validade inquestionada da lei de origem - mas tampouco paga após a declaração de inconstitucionalidade. Recurso extraordinário provido em parte (STF. Segunda Turma. Recurso extraordinário n. 122.202. Relator: Min. Francisco Rezek, de 10 de agosto de 1993. Diário da Justiça, 8 abr. 1994).

26 O marco final refere-se à data em que o acórdão estava disponível no sítio do Supremo Tribunal Federal e não à data do julgamento.

27 Seria possível argumentar que o objeto fosse delimitado primeiramente se definindo o conceito de "direito tributário" com supedâneo na doutrina nacional ou mesmo na estrangeira para, em seguida, se proceder à formação da base de dados. Essa alternativa seria problemática à medida que exigiria que o pesquisador soubesse de antemão todos os possíveis casos analisados pelo Supremo Tribunal Federal, para imediatamente classificá-los com fundamento no conceito adotado e finalmente determinar o conjunto de casos que constituiriam o objeto de estudo. Uma vez que não se é possível prever o conteúdo de todos os julgamentos já realizados ou, alternativamente, ler todos os casos já decididos pelo STF enquadrando-os ou não em "julgamentos de direito tributário", optou-se pela utilização de termos genéricos ("tributário", "tributação", "tributo") e da classificação já realizada pelo próprio tribunal, conforme se depreende do resultado das pesquisas de jurisprudência. Dito em outras palavras, o que o STF classificou como "tributário", "tributação" e "tributo" é, para fins da dissertação, "direito tributário".

28 O caso excluído foi a Petição Avulsa de Extradição 1085, na qual se pedia o relaxamento da prisão e a extradição de Cesare Battisti à Itália. (STF, Tribunal Pleno, Ext 1085 PET-AV, rel. min. Gilmar Mendes, rel. p/ acórdão min. Luiz Fux, j. em 08/06/2011, Dje 02/04/2013). 
ministros do STF, somente serão analisados os casos decididos pelo Plenário.

Uma vez delimitado o objeto a ser descrito e explorado, a jurisprudência do STF será analisada à luz de teorias que tratam do uso de argumentos consequencialistas por aplicadores do direito, de maneira geral, e por juízes, de maneira específica.

\section{Dos CONCEITOS ADOTADOS}

\subsection{O que se entende por argumentos consequencialistas e as manifestações do consequencialismo judicial}

A definição de argumentos consequencialistas é ambígua ${ }^{29}$, fazendo-se pertinente, portanto, determinar qual é aquela adotada ao longo deste trabalho.

A expressão é empregada aqui em sentido amplo para compreender qualquer "tipo de argumento que fornece razões para a tomada de uma decisão específica a partir de uma avaliação dos possíveis efeitos desta decisão" 30. O que importa para um juízo consequencialista é a consideração dos impactos na realidade de alternativas de decisão ou cursos de ação. Implicações puramente jurídicas de decisões, no sentido da representação de efeitos relevantes para o mundo e a linguagem do direito, não constituem argumentos propriamente consequencialistas, uma vez que se limitam à extração de resultados necessários determinados por normas ou manifestações autoritativas do direito, como uma decisão judicial. Tome-se, por exemplo, o contido no artigo 167 do Código Civil. A nulidade do negócio jurídico é uma consequência da declaração de simulação. Nesse caso, a nulidade é um efeito propriamente jurídico da decisão. Como tal, pode produzir efeitos no mundo. Mas são estes, e não aquele, que devem ser considerados em uma argumentação tipicamente consequencialista.

Partindo-se dessa definição, vê-se que o consequencialismo judicial comporta três visões distintas acerca da relevância de argumentos consequencialistas para a tomada de decisão. Na primeira delas, uma decisão é adequada se, e somente se, não se encontra uma decisão alternativa cujas consequências sejam preferíveis às suas, o que se poderia chamar de consequencialismo forte ${ }^{31}$. Já na segunda, as consequências exercem um papel residual nas decisões ${ }^{32}$, sendo utilizadas, somente, quando argumentos institucionais ${ }^{33}$ não forem capazes de determinar uma solução, o que se poderia denominar de consequencialismo residual. Por fim, na terceira, as consequências podem ser utilizadas ao lado de outros argumentos institucionais, mas nunca com peso superior a esses, o que se poderia classificar como consequencialismo fraco ${ }^{34}$.

29 MACCORMICK, Neil. On Legal Decisions and their Consequences: from Dewey to Dworkin. New York University Law Review, v. 58, n. 2, p. 246, maio 1983.

30 ARGUELHES, Diego Werneck. Argumentação Consequencialista e Estado de Direito: Subsídios para uma compatibilização. In: XIV Encontro Nacional do CONPEDI, 2005, Fortaleza. Anais do XIV Encontro Nacional do CONPEDI. Florianópolis: Fundação Boiteaux, 2005.

31 SCHUARTZ, Luis Fernando. Consequencialismo jurídico, racionalidade decisória e malandragem. p. 2-3. Disponível em: <http://bibliotecadigital.fgv.br/dspace/bitstream /handle/10438/1724/CONSEQUENCIALISMO;jsessionid=1D7FD074152F03813EF80E 88526D7381sequence=1>. Acesso em: 7 set. 2015.

32 SCHUARTZ, Luis Fernando. Consequencialismo jurídico, racionalidade decisória e malandragem. p. 2-3. Disponível em: < http://bibliotecadigital.fgv.br/dspace/bitstream /handle/10438/1724/CONSEQUENCIALISMO;jsessionid=1D7FD074152F03813EF80E 88526D7381 sequence=1>. Acesso em: 7 set. 2015.

33 "Os argumentos institucionais são aqueles que, sobre serem determinados por atos institucionais - parlamentares, administrativos, judiciais -, têm como ponto de referência o ordenamento jurídico. Possuem, nesse sentido, maior capacidade de objetivação." ÁVILA, Humberto. Argumentação Jurídica e a Imunidade do Livro Eletrônico. Revista Eletrônica de Direito do Estado, Salvador: Instituto Brasileiro de Direito Público, n. 21, jan./fev./mar., 2010.

34 SCHUARTZ, Luis Fernando. Consequencialismo jurídico, racionalidade decisória e malandragem. p. 2-3. Disponível em: < http://bibliotecadigital.fgv.br/dspace/bitstream /handle/10438/1724/CONSEQUENCIALISMO;jsessionid=1D7FD074152F03813EF80E 
Todas essas acepções preservam a mesma estrutura, que, nos termos de um modelo formal de justificação, pode ser apresentada em três etapas e duas dimensões. A primeira dessas etapas é a indicação clara das alternativas de decisão; a segunda, das consequências vinculadas a cada uma das alternativas decisórias. A relação entre os dois primeiros passos compõe a dimensão descritiva ou positiva do raciocínio consequencialista. Nela, realiza-se um esforço de prognose. A terceira etapa, por sua vez, diz respeito à identificação de um critério de valoração, para fins de ranqueamento ou ordenação, das consequências. A aplicação desse critério, com a correspondente ordenação dos estados do mundo antecipáveis e a seleção, ao fim, da alternativa decisória que deve ser privilegiada compõe a dimensão normativa do raciocínio. ${ }^{35}$ Essa estrutura ergue a pretensão de se aplicar a qualquer processo de tomada de decisão orientado em efeitos futuros de alternativas decisórias. ${ }^{36}$ A diferença entre as três acepções de consequencialismo anteriormente apresentadas, portanto, não é estrutural, mas reside no peso atribuído aos argumentos consequencialistas para a determinação da decisão.

A definição ampla de argumentos consequencialistas e consequencialismo judicial no presente trabalho se justifica por permitir a análise de um número maior de decisões do Supremo Tribunal Federal nos quais essa estrutura de argumentação se fez presente ${ }^{37}$. Como resultado, acredita-se que certos problemas atrelados à argumentação com base em consequências possam ser visualizados mais facilmente, fortalecendo o debate quanto à sua utilização no processo de tomada de decisões.

\subsection{Modulação temporal da declaração de inconstitucionalidade}

No Direito brasileiro, prevalece a regra geral de que a declaração de inconstitucionalidade de lei ou ato normativo federal ou estadual opera efeitos ex tunc, retroagindo à data de origem do ato viciado ${ }^{38}{ }_{-}^{39}$ e ces- $^{-}$ sando, imediatamente, a sua aplicação $0^{40}$. Tais declarações de inconstitucionalidade, se proferidas em sede de controle concentrado, produzem eficácia contra todos e efeito vinculante em relação aos demais órgãos do Poder Judiciário e à Administração Pública direta e indireta de todos os entes da Federação, nos termos do art. 102, \2º da Constituição Federal de 1988.

A questão, no entanto, torna-se complexa quando se reconhece que, em que pese a eficácia declaratória das decisões de inconstitucionalidade, a norma inválida de fato produziu seus efeitos no mundo real ${ }^{41}$, de tal sorte que a atribuição de efeitos ex tunc, em determinadas hipóteses, seria capaz de "violar ainda mais a

88526D7381 sequence=1>. Acesso em: 7 set. 2015.

35 ARGUELHES, Diego; LEAL, Fernando. Pragmatismo como [Meta] Teoria Normativa da Decisão Judicial: Caracterização, Estratégias e Implicações. In: SARMENTO, Daniel Antonio de Moraes (Org.). Filosofia e Teoria Constitucional Contemporânea. Rio de Janeiro: Lumen Juris, 2009. p. 190.

36 Um esforço nesse sentido pode ser encontrado em LEAL, Fernando. Ziele und Autorität: Zu den Grenzen teleologischen Rechtsdenkens. Baden-Baden: Nomos, 2014.

37 Uma definição mais restrita de argumentos consequencialistas na seara tributária é defendida pela professora Tathiane dos Santos Piscitelli para quem "se a consequência com a qual devemos nos preocupar é aquela vinculada à universalidade da decisão, um argumento consequencialista válido (ou seja, que esteja focado nas consequências que importam) deverá tratar da aceitabilidade da aplicação universal da decisão em face dos valores do direito tributário." PISCITELLI, Tathiane dos Santos. Argumentando pelas consequências no direito tributário. São Paulo: Noeses, 2011. p. 32.

38 A declaração de inconstitucionalidade proferida em controle concentrado, de acordo com o precedente firmado pelo Supremo Tribunal Federal no julgamento do RE 730462, não tem o condão de atingir decisões transitadas em julgado. Nesses casos, seria necessária a propositura de uma ação rescisória para desconstituição da coisa julgada.

39 De acordo com Luís Roberto Barroso, "[n]ão prevaleceu no Brasil a doutrina que atribuía à lei inconstitucional a condição de norma anulável, dando à decisão na matéria um caráter constitutivo". (BARROSO, Luís Roberto. O controle de constitucionalidade no direito brasileiro: exposição sistemática da doutrina e análise crítica da jurisprudência. 3. ed. São Paulo: Saraiva, 2008. p. 198.

40 SILVA, José Afonso da. Curso de Direito Constitucional Positivo. 35. Ed. São Paulo: Malheiros Editores, 2012. p. 54-55.

41 Nesse sentido, desde 1977, já se falava em produções de efeitos das normas as quais não podiam ser ignoradas pelo Supremo Tribunal Federal. O ministro Leitão de Abreu, no RE 79343, afirma: “[t]enho que procede a tese de que a lei inconstitucional é um fato eficaz, ao menos antes da determinação da inconstitucionalidade, podendo ter consequências que não é lícito ignorar." 
Constituição" STF no sentido da inconstitucionalidade da norma, seus efeitos, ou parte deles, sejam mantidos. A declaração de inconstitucionalidade passa a operar efeitos ex nunc (a partir da publicação da decisão) ou a partir de outro momento fixado pelo Tribunal, sendo possível, ademais, o estabelecimento de regras de transição que visem à promoção, na maior medida possível, da ordem constitucional ${ }^{43}$

O ordenamento brasileiro passou a admitir, expressamente, a modulação temporal no art. 27 da Lei 9.868/199944 embora, em ocasiões anteriores, o Supremo Tribunal Federal já houvesse identificado a impossibilidade de atribuição de efeitos retroativos ante a necessidade de se proteger a boa-fé do particular nas suas relações com o poder público ${ }^{45}$.

Nos termos do art. 27 da Lei 9868/1999, a modulação temporal deve se dar por razões de "segurança jurídica" ou de "excepcional interesse social", não se aplicando essa regra aos casos de declaração de constitucionalidade ${ }^{46}$.

Ainda que o dispositivo seja amplamente utilizado pelo Supremo Tribunal Federal, sua constitucionalidade está sendo questionada nas ADIs 2154 e 2258, propostas, respectivamente, pela Confederação Nacional das Profissões Liberais e pelo Conselho Federal Da Ordem Dos Advogados Do Brasil. Dentre outros argumentos, segundo os autores, a norma seria contrária à isonomia, à legalidade e ao devido processo legal ${ }^{47}$.

Longe de procurar esgotar a discussão quanto à modulação dos efeitos da declaração de inconstitucionalidade $^{48}$, esta seção tem a finalidade de evidenciar duas questões cruciais para o desenvolvimento do presente trabalho.

A primeira delas diz respeito ao caráter excepcional da modulação, o que impõe aos ministros um ônus argumentativo a ser superado para fundamentar a sua aplicação. Assim, eles devem (i) justificar, expressamente, por que a nulidade ex tunc é afastada, apontando o fundamento da norma constitucional que serve de base para a preservação dos efeitos do ato inconstitucional, (ii) justificar como o afastamento da nulidade ex tunc é capaz de manter o estado de constitucionalidade e (iii) indicar os efeitos negativos advindos da decretação da nulidade $e x$ tunc $^{49}$.

A segunda questão está relacionada ao entendimento de que, tal como prevista no ordenamento jurídico brasileiro, a modulação requer que os ministros pensem nas consequências de suas decisões. Isso porque, primeiramente, se lhes cabe comprovar os efeitos negativos que adviriam da decretação da nulidade ex tunc e fundamentar como o seu afastamento é capaz de manter o estado de constitucionalidade, então, é necessário que os ministros considerem, e antecipem, os estados de coisas vinculados às alternativas decisórias de

42 ÁVILA, Humberto. Sistema Constitucional Tributário. 5. ed. São Paulo: Saraiva, 2012. p. 363.

43 ÁVILA, Humberto. Teoria dos Princípio: Da definição à aplicação dos princípios jurídicos. 16. ed. São Paulo: Malheiros Editores, 2015. p. 515.

44 In verbis: Ao declarar a inconstitucionalidade de lei ou ato normativo, e tendo em vista razões de segurança jurídica ou de excepcional interesse social, poderá o Supremo Tribunal Federal, por maioria de dois terços de seus membros, restringir os efeitos daquela declaração ou decidir que ela só tenha eficácia a partir de seu trânsito em julgado ou de outro momento que venha a ser fixado.

45 A título meramente exemplificativo, tem-se o RE 79343, Segunda Turma, Rel. Min. Leitão de Abreu, jul. em 31/05/1977, DJ $02 / 09 / 1977$.

46 O STF rejeitou esta possibilidade no julgamento dos Embargos de Declaração na ADI 1040, sob o argumento de que se admitida a modulação, ter-se-ia uma inversão da presunção de constitucionalidade das leis. (ED na ADI 1040, Tribunal Pleno, Rel. Min. Ellen Gracie, jul. em 31/05/2006, DJ 01/09/2006).

47 O julgamento das ADIs foi suspenso em fevereiro de 2007. Disponível em: <http://www.stf.jus.br/portal/cms/verNoticiaDetalhe.asp?idConteudo $=69099>$.

48 Para uma análise mais aprofundada sobre o tema, ver ÁVILA, Humberto. Teoria da Segurança Jurídica. $3^{a}$ Ed. São Paulo: Malheiros Editores, 2014. p. 514-595 e DERZI, Misabel Abreu Machado. Modificações da jurisprudência: proteção da confiança, boa-fé objetiva e irretroatividade como limitações constitucionais ao poder judicial de tributar. São Paulo: Noeses, 2009. Capítulo V. Para uma crítica ao excepecional interesse social como critério para modulação devido à sua indeterminação conceitual, ver ÁVILA, Ana Paula. A modulação de Efeitos Temporais pelo STF no Controle de Constitucionalidade. Porto Alegre: Livraria do Advogado Editora, 2009.

49 ÁVILA, Humberto. Teoria da Segurança Jurídica. 3. ed. São Paulo: Malheiros, 2014. p. 594. 
modulação ou não dos efeitos temporais da decisão. Tais prognoses, como se nota, são parte de uma argumentação consequencialista que demanda a análise de alternativas, a indicação das respectivas consequências vinculadas a cada uma delas e a escolha da alternativa que gere os melhores efeitos no mundo real, a partir do critério normativamente eleito para a hierarquização dos estados do mundo.

A modulação, também, demanda dos ministros uma argumentação consequencialista por uma segunda razão, relativa à estrutura das normas.

Os critérios para a modulação de efeitos da decisão declaratória de inconstitucionalidade, i.e., segurança jurídica e excepcional interesse social ${ }^{50}$, determinados por expressa escolha do legislador infraconstitucional, são princípios jurídicos, diferenciando-se em sua estrutura das regras. Conforme Humberto Ávila,

Princípios são normas imediatamente finalísticas, primariamente prospectivas e com pretensão de complementariedade e de parcialidade, para cuja aplicação se demanda uma avaliação da correlação entre o estado de coisas a ser promovido e os efeitos decorrentes da conduta havida como necessária à sua promoção ${ }^{51}$.

Dessa forma, os critérios que possibilitam a modulação de efeitos, em que pese indiquem um estado de coisas a ser promovido, não prescrevem o meio para alcançá-lo, estando o intérprete da norma livre para fixá-lo. A liberdade de escolha de meios se evidencia pelas diversas alternativas de como modular o efeito da decisão. Em linhas meramente exemplificativas, é possível a atribuição de efeitos ex nunc, a criação de regras de transição e o estabelecimento de um período de tempo no qual a norma ainda produzirá seus efeitos. Isso significa que o juiz tem liberdade para escolher, dentre os meios possíveis, aquele que produzirá consequências que promoverão, na maior medida, o estado de coisas buscado pela segurança jurídica e pelo excepcional interesse social.

\section{A utilização de argumentos Consequencialistas na JURISPRUdênCia do SuPRemo Tribunal Federal}

Em relação aos 31 acórdãos analisados, em 25 constatou-se a utilização de argumentos consequencialis$\operatorname{tas}^{52}$. Embora referências genéricas aos efeitos da decisão sejam recorrentes — no RE 377457, por exemplo, a ministra Cármen Lúcia disse considerar a questão discutida "realmente, gravíssima [...] até pelas consequências que daqui derivam", enquanto que o ministro Menezes Direito, destacou a "repercussão" do caso e o "efeito danoso" a "pequenos contribuintes" —, é notável a capacidade de os ministros elaborarem cadeias de consequências que, em última instância, culminariam não somente no desestímulo "[a]os cidadãos em geral a respeitarem o arcabouço normativo constitucional em vigor" (ADI 4481), como também à institui-

50 Em um debastamento inicial sobre o tema, vê-se que o Supremo Tribunal Federal tem interpretado excepecional interesse social de maneira bem abrangente, consubstanciando-se esse em qualquer princípio constitucional. SANTI, Eurico Marcos Diniz de. A Modulação no Controle de Constitucionalidade de Novos Tributos. Revista Consultor Jurídico, 10 jul. 2014. Disponível em: < http:// www.conjur.com.br/2014-jul-10/eurico-santi-modulacao-supremo-criacao-tributo >. Acesso em: 18 set. 2015.

51 ÁVILA, Humberto. Teoria dos Princípio: Da definição à aplicação dos princípios jurídicos. 16. ed. São Paulo: Malheiros Editores, 2015. p. 102.

52 Eurico de Santi, ao analisar a modulação de efeitos da declaração de inconstitucionalidade nos casos relativos à instituição de novos tributos, chega à conclusão de que a repercussão econômica nunca é critério suficiente para determinar a modulação. Segundo o professor, "o STF sempre se pautou por razões de lacuna normativa, alteração de entendimento jurisprudencial e, em última instância, de insegurança no sistema jurídico". SANTI, Eurico Marcos Diniz de. A Modulação no Controle de Constitucionalidade de Novos Tributos. Revista Consultor Jurídico, 10 jul. 2014. Disponível em: < http://www.conjur.com.br/2014-jul-10/eurico-santimodulacao-supremo-criacao-tributo $>$. Acesso em: 18 set. 2015. A afirmação do professor deve ser lida nos exatos termos em que foi proposta. Primeiramente, ela diz respeito a um tipo específico de casos, qual seja, relativo à instituição de novos tributos. Em segundo lugar, embora a repercussão econômica não seja critério suficiente para determinar a modulação, isso não significa, necessariamente, que ela não seja considerada pelos ministros. O presente trabalho adota um conceito mais amplo de consequencialismo judicial, conforme descrito na metodologia, de forma que neste capítulo são analisados os diversos argumentos consequencialistas presentes nas decisões relativas a modulação, independente do peso que cada um deles exerceu para determinar a decisão. 
ção, pelo Supremo, do "capitalismo sem as incertezas inerentes às decisões de produção e de investimento, o capitalismo sem riscos, sem o salto no escuro" (RE 353657).

Neste tópico pretende-se responder ao problema formulado nas considerações introdutórias, qual seja, se os juízos de prognose inerentes à argumentação com base em consequências, quando realizados pelos ministros do STF, são acompanhados de documentos, estudos ou dados capazes de lhes servir de suporte. Uma vez verificada a confirmação da hipótese, analisa-se, criticamente, a utilização de argumentos consequencialistas na jurisprudência do STF e se questiona, dada a assimetria existente entre o futuro presente e o presente futuro que afeta a confiabilidade das prognoses em juízos prospectivos ${ }^{53}$, se os ministros reúnem informações capazes de superar deficits epistêmicos no processo de justificação de decisões orientados em consequências.

\subsection{Respostas aos problemas de pesquisa (ou a falta de evidências empíricas para a elaboração de prognoses)}

A tabela abaixo demonstra se argumentos consequencialistas foram ou não considerados em cada um dos julgamentos analisados e, em casos afirmativos, se as prognoses foram acompanhadas de estudos, documentos ou dados que lhes servissem de suporte.

Tabela 1

\begin{tabular}{|c|c|c|c|c|}
\hline \multicolumn{2}{|c|}{ Caso } & \multirow[t]{2}{*}{\begin{tabular}{|l|} 
Tema \\
ICMS
\end{tabular}} & \multirow[t]{2}{*}{$\begin{array}{l}\text { Há argumento } \\
\text { consequen- } \\
\text { cialista? }\end{array}$} & \multirow[t]{2}{*}{$\begin{array}{l}\text { A prognose é acompanha- } \\
\text { da, no voto dos ministros, } \\
\text { de documentos, estudos } \\
\text { ou dados, capazes de lhe } \\
\text { servir de suporte? } \\
\text { Não }\end{array}$} \\
\hline 01 & ADI 4171 & & & \\
\hline 02 & QO na ADI 4425 & Precatório & Sim & Em parte $^{1 *}$ \\
\hline 03 & ADI 4481 & ICMS & Sim & Não \\
\hline 04 & ED no RE 595838 & CSLL & Sim & Em parte* \\
\hline 05 & ED no RE 569056 & $\begin{array}{l}\text { Execução fiscal pela Ju- } \\
\text { stiça do Trabalho }\end{array}$ & Sim & Em parte* \\
\hline 06 & RE 590809 & IPI & Sim & Não \\
\hline 07 & RE 477323 & ICMS & Não & ------ \\
\hline 08 & RE 635688 & ICMS & Não & ----- \\
\hline 09 & ED no RE 559937 & ICMS & Sim & Não \\
\hline 10 & ADI 4628 & ICMS & Sim & Não \\
\hline 11 & RE 680089 & ICMS & Sim & Não \\
\hline 12 & ADI 429 & ICMS & Sim & Não \\
\hline 13 & AgR na Rcl 12692 & $\begin{array}{l}\text { Contribuição social pre- } \\
\text { videnciária do produtor } \\
\text { rural }\end{array}$ & Não & ------ \\
\hline 14 & ADI 2669 & ICMS & Sim & Não \\
\hline 15 & RE 630733 & Concurso público & Sim & Não \\
\hline 16 & RE 559937 & PIS/COFINS & Sim & Não \\
\hline
\end{tabular}

53 LUHMANN, Niklas. Selbstreferenz und Teleologie in gesellschaftstheoretischer Perspektive. Neue Hefte für Philosophie, Göttingen, v. 20, p. 6-7, 1981. 


\begin{tabular}{|c|c|c|c|c|}
\hline \multicolumn{2}{|c|}{ Caso } & \multirow{2}{*}{\begin{tabular}{|l|} 
Tema \\
$\begin{array}{l}\text { Imposto sobre impor- } \\
\text { tação }\end{array}$
\end{tabular}} & \multirow{2}{*}{$\begin{array}{l}\text { Há argumento } \\
\text { consequen- } \\
\text { cialista? }\end{array}$} & \multirow{2}{*}{$\begin{array}{l}\text { A prognose é acompanha- } \\
\text { da, no voto dos ministros, } \\
\text { de documentos, estudos } \\
\text { ou dados, capazes de lhe } \\
\text { servir de suporte? } \\
\text { Não }\end{array}$} \\
\hline 17 & RE 405579 & & & \\
\hline 18 & RE 596177 & $\begin{array}{l}\text { Contribuição social pre- } \\
\text { videnciária do produtor } \\
\text { rural }\end{array}$ & Não & ----- \\
\hline 19 & ADI 3462 & Remissão e anistia & Sim & Não \\
\hline 20 & ADI 875 & $\begin{array}{l}\text { Fundo de Participação } \\
\text { dos Estados }\end{array}$ & $\operatorname{Sim}$ & Não \\
\hline 21 & RE 363852 & $\begin{array}{l}\text { Contribuição social pre- } \\
\text { videnciária do produtor } \\
\text { rural }\end{array}$ & Sim & Não \\
\hline 22 & RG no RE 592321 & IPTU & Não & ----- \\
\hline 23 & RE 377457 & COFINS & Sim & Não \\
\hline 24 & RE 556664 & Prescrição e decadência & Sim & Não \\
\hline 25 & RE 560626 & Prescrição e decadência & Sim & Não \\
\hline 26 & RE 559943 & Prescrição e decadência & Sim & Não \\
\hline 27 & RE 353657 & IPI & Sim & Em parte* \\
\hline 28 & RE 370682 & IPI & Sim & Em parte* \\
\hline 29 & MC em ADI 3090 & $\begin{array}{l}\text { Comercialização de ener- } \\
\text { gia elétrica }\end{array}$ & Sim & Não \\
\hline 30 & $\begin{array}{l}\text { ED nos ED no RE } \\
256588\end{array}$ & $\begin{array}{l}\text { Taxa de serviço de lim- } \\
\text { peza e de coleta de lixo }\end{array}$ & $\operatorname{Sim}$ & Não \\
\hline 31 & MC em ADI 2251 & Medida Provisória & Não & ----- \\
\hline
\end{tabular}

${ }^{*}$ Nem todas as prognoses foram acompanhadas, no voto dos ministros, de documentos, estudos ou dados.

Antes de analisar a tabela, duas considerações são pertinentes. A primeira delas é referente a uma possível crítica que poderia ser endereçada à operacionalização da pesquisa e a segunda relativa ao preenchimento das variáveis presentes na tabela.

Inicialmente, deve-se afastar a possibilidade de que uma eventual consequência alegada por um ministro, embora não encontrasse suporte em seu voto, estivesse amparada em estudos, documentos ou dados trazidos pelas partes ao longo do processo. Isto porque, ainda que assim o fosse, simplesmente se identificaria um novo problema, já que dado o dever de os juízes fundamentarem suas decisões (art. 93, IX, Constituição Federal de 1988), indicando as razões do seu convencimento (art. 371 do Novo Código de Processo Civil), não poderiam os ministros alegar, genericamente, as consequências advindas das suas decisões sem fazer constar, expressamente, os estudos que lhes permitiram concluir pela possibilidade de que os resultados descritos não passassem de meras intuições e especulações.

Quanto às variáveis da tabela, partindo-se da conceituação do capítulo 2, verificou-se a presença ou ausência de argumentos consequencialistas no voto dos ministros. No tocante a documentos, estudos ou dados que pudessem servir de suporte para as prognoses, era necessário que os ministros indicassem um (i) documento/estudo/dado (ii) específico sobre o caso (iii) produzido por terceiro alheio ao processo, ainda que 
a requerimento das partes ou em razão de determinação judicial. Este não é o caso, por exemplo, da citação de livro genérico sobre análise econômica do direito, como o fez no RE 405579 o ministro Gilmar Mendes. Em seu voto, o ministro cita o manual de Law and Economics de Cooter e Ulen para corroborar com a sua tese de que a oferta de produtos poderia impactar no equilíbrio de mercado e na inflação, algo considerado insuficiente para embasar uma prognose, já que a obra não trata especificamente sobre o tema em discussão. Em sentido oposto, foram consideradas reportagens de jornais que indicassem potenciais efeitos da decisão, como no RE 353657, no qual o ministro Marco Aurélio destaca um artigo de Miriam Leitão no qual a autora afirma que "decidir contra o recurso pode causar uma sangria absurda nos cofres públicos".

Feitos esses esclarecimentos, em relação aos 25 casos em que houve a utilização de argumentos consequencialistas, somente em 5 fez-se referência a algum estudo, dado ou documento que pudesse embasar as prognoses feitas pelos ministros.

Portanto, a pesquisa mostra que, em $80 \%$ dos casos nos quais os ministros argumentaram a partir das consequências de alternativas de decisão, não houve qualquer prova que justificasse que a prognose fosse (i) possível, no sentido de ser uma decorrência da alternativa de decisão escolhida, ou (ii) provável, no sentido de que se escolhida a alternativa, haveria chances de a prognose ser realizada no mundo real.

Dessa forma, a hipótese de pesquisa é confirmada: a maior parte dos juízos prognósticos não são acompanhados de documentos, estudos ou dados capazes de lhes servir de suporte. Isto evidencia que grande parte das consequências que os ministros atribuem como sendo efeitos de suas decisões não vão além de meras intuições e suposições cuja concretização, no mundo real, talvez não seja certa ou mesmo possível.

Ainda que, em hard cases, a mera menção às fontes do direito não seja suficiente para a aceitação racional da decisão pela comunidade jurídica ${ }^{54}$, não se pode conceder aos ministros uma carta branca para que, buscando os melhores efeitos de suas decisões, eles se eximam do seu dever de justificação das decisões. Dessa forma, a mera referência ao artigo 27 da Lei 9868/1999 não é motivação suficiente para justificar a modulação dos efeitos da decisão com base nas possíveis consequências positivas advindas da adoção de tal postura. Os ministros deveriam tornar explícitas as razões que lhe permitiram concluir pela adoção de uma determinada alternativa decisória.

Nesse sentido, a confirmação da hipótese é problemática porque coloca em dúvida até que ponto as decisões proferidas pelos ministros são racionalmente fundamentadas. Ao que tudo indica, nos julgamentos tributários nos quais se discutiu a modulação dos efeitos da declaração de inconstitucionalidade, a argumentação com base em consequências parece dever ser rechaçada, já que, da forma como é operacionalizada pelos ministros, conduz a mais arbitrariedades, uma vez que não enfrenta as incertezas estruturais que afetam a dimensão descritiva de argumentações consequencialistas, do que propriamente a uma motivação racional preocupada com os efeitos da decisão no mundo prático.

Antes de se passar à análise crítica da jurisprudência do tribunal, vale a pena olhar mais a fundo os cinco casos em que as prognoses dos ministros não parecem ter sido fruto de meras intuições.

Nesse momento, é pertinente a introdução da Tabela 2, na qual se constatam quais argumentos consequencialistas foram mais utilizados nas decisões envolvendo a modulação em julgamentos de Direito Tributário.

54 AARNIO, Aulis. Essays on the Doctrinal Study of Law. Heidelberg: Springer, 2011. p. 136. 
Tabela $2^{55^{*}}$

\begin{tabular}{|c|c|c|}
\hline Número & Casos & Qual argumento consequencialista? \\
\hline 12 & $\begin{array}{l}\text { ADI 4171, QO na ADI 4425, ED no } \\
\text { RE 595838, ED no RE 569056, ED } \\
\text { no RE 559937, RE 680089, ADI 4628, } \\
\text { ADI 429, ADI 2669, RE 559937, RE } \\
\text { 353657, RE } 370682\end{array}$ & Arrecadação/finanças \\
\hline 2 & RE 559943, RE 370682 & Enriquecimento ilícito \\
\hline 7 & $\begin{array}{l}\text { ADI 4171, QO na ADI 4425, ADI } \\
\text { 4481, RE 630733, RE 363852, RE } \\
\text { 353657, ED nos ED no RE } 256588\end{array}$ & $\begin{array}{l}\text { Ação oportunística/ incentivo à adoção de compor- } \\
\text { tamentos }\end{array}$ \\
\hline 4 & $\begin{array}{l}\text { QO na ADI 4425, ADI 429, RE } \\
377457 \text {, RE } 370682\end{array}$ & Impacto no exercício de direito de terceiros \\
\hline 3 & $\begin{array}{l}\text { QO na ADI 4425, ADI 875, MC em } \\
\text { ADI } 3090\end{array}$ & Promoção/preocupação com o diálogo institucional \\
\hline 12 & $\begin{array}{l}\text { RE 590809, ED no RE 569056, ED } \\
\text { no RE 559937, RE 680089, ADI } \\
\text { 4628, RE 630733, RE 559937, ADI } \\
\text { 875, RE 363852, RE 559943, RE } \\
\text { 353657, RE } 370682\end{array}$ & $\begin{array}{l}\text { Aumento/existência de múltiplos litígios e morosida- } \\
\text { de do Judiciário }\end{array}$ \\
\hline 3 & ADI 2669, RE 630733, RE 405579 & $\begin{array}{l}\text { Tratamento isonômico dos contribuintes/proteção } \\
\text { da concorrência }\end{array}$ \\
\hline 2 & RE 405579, RE 353657 & $\begin{array}{l}\text { Equilíbrio de mercado, consumo interno e inflação/ } \\
\text { efeitos sobre o capitalismo }\end{array}$ \\
\hline
\end{tabular}

Em relação à leitura das Tabelas 1 e 2, percebe-se que, nos cinco julgamentos nos quais as prognoses foram acompanhadas de documentos, os principais argumentos consequencialistas diziam respeito à arrecadação ou às finanças do Estado. Desses, em quatro buscava-se demonstrar a perda de arrecadação do Fisco caso se optasse pela decretação da nulidade ex tunc (ED no RE 595838, ED no RE 569056, RE 353657 e RE 370682). Em três os dados foram retirados da própria argumentação da Fazenda Nacional (ED no RE 595838, ED no RE 569056 e RE 370682). A modulação foi afastada nos dois embargos de declaração sob o argumento de que "[a] mera alegação de perda de arrecadação não é suficiente para comprovar a presença do excepcional interesse social" 56 .

Analisando cada caso de maneira isolada, talvez não se vislumbre nenhum problema. As incongruências são reveladas quando se tenta compatibilizar as diferentes decisões do Supremo. Se a alegação de perda de arrecadação não é suficiente para modular a declaração da inconstitucionalidade quando se sabe, claramente, o prejuízo financeiro do Estado, seria de se imaginar que menores razões tivesse o tribunal para optar pela modulação quando os prejuízos fossem incertos e a prognose fosse descrita em termos meramente genéricos. No entanto, na ADI 4171, o tribunal decidiu, por maioria ${ }^{57}$, vencido o ministro Marco Aurélio, pela modulação, já que a decisão "implicar[ia] sérias repercussões aos contribuintes e aos Estados-sedes das distribuidoras de combustíveis, que ter[iam] suas arrecadações diminuídas abruptamente".

Em relação aos cinco julgamentos mencionados linhas acima em que foram apresentados suportes em-

$55{ }^{*}$ A preponderância de tipos específicos de argumentos consequencialistas não significa que outros não tenham sido utilizados.

56 Trecho retirado do voto do Ministro Dias Toffoli nos ED no RE 595838.

57 O ministro Dias Toffoli, relator dos ED no RE 595838 e ED no RE 569056, estava ausente no julgamento da ADI 4171. 
píricos para as prognoses elaboradas pelos ministros, em apenas um (QO na ADI 4425) o argumento consequencialista preponderante era relativo às finanças do Estado.

O objeto da QO na ADI 4425 era a modulação dos efeitos da declaração de inconstitucionalidade de diversos dispositivos da Emenda Constitucional (EC) no 62/09, que alterou a sistemática dos precatórios, concedendo um prazo de 15 anos para que os Estados, o Distrito Federal e os Municípios realizassem os pagamentos. Um dos principais pontos de debate entre os ministros foi por quanto tempo dever-se-ia prolongar os efeitos da norma, dada a impossibilidade de os Estados cumprirem, imediatamente, a decisão judicial que declarara a inconstitucionalidade do regime.

O ministro Luís Roberto Barroso, em particular, ressaltou o fato de que, mesmo se tratando de uma emenda inconstitucional, seriam inegáveis os avanços por ela promovidos, já que "pela primeira vez, desde o início da vigência da Constituição de 88", Estados e Municípios haveriam sido retirados da "inércia cômoda", na qual de maneira reiterada descumpriam o pagamento de precatórios. O ministro ainda se demonstrou preocupado com a possibilidade de que, se não fossem mantidos os efeitos da norma inconstitucional por um período no tempo, os Estados passariam, novamente, a descumprir os precatórios. Daí a afirmação de Barroso:

o pior serviço que o Supremo Tribunal Federal poderia prestar ao País seria entregar de volta à sociedade, ou entregar de volta aos credores, uma situação de fato pior do que aquela que eles tinham com a Emenda Constitucional n ${ }^{\circ} 62$.

Se o Supremo já havia reconhecido que a moratória de 15 anos prevista na EC no 62/09 era inconstitucional, mas igualmente a declaração de nulidade ex tunc poderia levar a uma inobservância ainda maior do ordenamento jurídico, questão de mais difícil resolução entre os ministros era por quantos anos os efeitos da norma deveriam ser estendidos. Nas palavras do ministro Gilmar Mendes:

[h]á uma grande responsabilidade na fixação apenas desse prazo, se é o caso, porque, se fosse de um ano ou de cinco anos, significa que, no próximo orçamento, o Estado terá de arcar com os custos normais dos precatórios mais o estoque para liquidá-los de uma só vez.

O cerne do problema poderia ser formulado nos seguintes termos: por quantos anos deveriam ser estendidos os efeitos da norma inconstitucional para que os Estados pudessem cumprir com os precatórios?

Aqui, evidenciam-se dois problemas distintos da argumentação consequencialista.

O primeiro se evidencia no voto do ministro Gilmar Mendes. No começo do julgamento, o ministro apresentou um estudo realizado pelo professor José Roberto Afonso, um dos responsáveis pela criação da Lei de Responsabilidade Fiscal, e por Gabriel Leal de Barros, ambos do Grupo de Gestores de Finanças Estaduais. O estudo apontava que 62\% dos Estados teriam capacidade de pagar os precatórios em 15 anos, prazo estipulado na $\mathrm{EC} \mathrm{n}{ }^{\circ}$ 62/09. Dos 38\% restantes, porém, alguns sequer teriam condições de se adaptar ao novo regime instituído pela emenda. Inicialmente, essa informação demonstra que, mesmo que a inconstitucionalidade da norma não houvesse sido declarada, ainda assim, no mundo fático, vários estados não conseguiriam arcar com os seus débitos. Isto já é suficiente para por em dúvidas se o resultado esperado pela modulação, qual seja, o pagamento dos precatórios, teria como de fato ser alcançado.

O segundo problema pode ser percebido no voto do ministro Luís Roberto Barroso. No caso analisado, o ministro pareceu incorporar, em alguma medida, o estudo apresentado por Gilmar Mendes, ao entender que a mera redução do prazo de moratória não seria suficiente para estimular o pagamento dos precatórios. O ministro deu um passo seguinte, concluindo pela necessidade de adoção de outras medidas que pudessem viabilizar o pagamento dos precatórios por parte dos Estados.

Uma das principais propostas do ministro, nesse contexto, foi o aumento do grau de comprometimento da receita corrente líquida dos Estados, a ser feita com base na "percepção geral" de que "o máximo de vinculação possível é 3\%”. Em relação à impossibilidade de pagamento dos precatórios em 15 anos, evidencia- 
da na pesquisa do Grupo de Gestores de Finanças Estaduais (GEFIN), Barroso concluiu pela necessidade de mecanismos alternativos. Inexiste qualquer informação no sentido de que o comprometimento forçado de 3\% da receita corrente líquida dos Estados incentivará os Estados a arcarem com as suas dívidas. A decisão do ministro é problemática porque (i) não encontra suporte no estudo do GEFIN, (ii) a "percepção geral" pode ser equivocada e (iii) o fato de o Município de São Paulo, "o principal devedor do país", dizer "que os 3\% são compatíveis com a sua receita corrente líquida e com as suas outras obrigações" não significa necessariamente a compatibilidade dessa mesma porcentagem com a receita corrente líquida de todos os outros Estados e Municípios do país e do Distrito Federal. Assim, de forma abstrata, poder-se-ia descrever o problema da argumentação do ministro como um relativo à utilização inconsistente de provas, na qual um estudo inicialmente feito para a prognose P, é utilizado para a criação e sustentação de uma prognose P'.

Todos os cinco julgamentos em que se verificou a existência de dados embasando as prognoses elaboradas pelos ministros revelam, em certa medida, as incongruências de argumentações com base em consequências quando realizadas no STF. Na resolução de um caso específico, como na QO na ADI 4425, o estudo apresentado, se levado a sério, colocaria em xeque não somente os efeitos esperados da modulação, como também a qualidade da regra criada pelo $\mathrm{STF}^{58}$. Em uma perspectiva dinâmica, vê-se que o Tribunal não fornece critérios mínimos que permitam determinar quais consequências serão levadas em consideração. A existência de pesquisa, dados e estudos, os quais teoricamente serviriam de suporte para prognoses indicando a probabilidade de elas de fato virem a se materializar, parece ser irrelevante, já que o STF não modulou casos em que haviam fortes indícios corroborando os efeitos de suas decisões e modulou outros em que as consequências eram incertas e duvidosas.

\subsection{Análise crítica}

Nesta seção, analisa-se, criticamente, a utilização de argumentos consequencialistas na jurisprudência do Supremo. A partir da descrição realizada, defende-se que esse tipo de argumentação deveria ser evitado pelos ministros, ante a existência de deficiências epistêmicas que comprometem o uso de consequências para a determinação de decisões.

Os dados analisados corroboram a tese de deficit epistêmico ao revelarem que (i) os ministros têm dificuldade de, a partir da consideração de casos diferentes, tratar o mesmo tipo de argumento consequencialista de forma uniforme, sendo tal fato evidenciado pelo tratamento diverso de prognoses idênticas a depender do caso submetido à análise do Tribunal; e (ii) os ministros elaboram prognoses e criam cadeias de consequências sem que haja qualquer prova ou presunção legal indicando a possibilidade de sua realização. Cada um desses pontos será abordado de maneira mais detalhada a seguir.

\subsubsection{Tratamento diverso a tipos idênticos de consequência}

Em uma perspectiva dinâmica, a dificuldade de os ministros abordarem as consequências de forma uniforme é evidente principalmente nos julgamentos envolvendo a utilização de argumentos consequencialistas relativos ao aumento de litígios nas hipóteses de afastamento da modulação dos efeitos temporais da decisão. Nesse sentido, é interessante comparar as decisões proferidas nos ED no RE 569056 e no RE 680089 com aquela da QO na ADI 4425.

58 O ministro Marco Aurélio votou vencido contra a modulação, criticando o posicionamento dos demais por atuarem, na sua visão, como legisladores positivos. "Vossa Excelência me permite? A meu ver, com a devida vênia, há dois aspectos que consubstanciam, sob minha óptica, obstáculo intransponível: o primeiro é que não podemos atuar como legisladores positivos, muito menos para alterar a Carta da República. O segundo é que precatório está jungido a orçamento, e, portanto, deve ser liquidado conforme a força do orçamento, e não de depósitos judiciais que estão fora da esfera do Estado, propriamente dito, em termos de disponibilidade, já que são feitos e vinculados a certa relação jurídica processual." (trecho da manifestação do ministro Marco Aurélio na QO na ADI 4425, Tribunal Pleno, Rel. Min. Luiz Fux, j. em 25/03/2015, DJe 03/08/2015). 
Nos ED no RE 569056, demandava-se a modulação temporal da decisão que reconhecera a competência da Justiça do Trabalho para executar as contribuições previdenciárias relativas exclusivamente ao objeto da condenação constante das suas sentenças. Contra a alegação da Fazenda Nacional de que a declaração de improcedência dos embargos levaria a um aumento dos litígios judiciais, o ministro Dias Toffoli declarou que esta não passaria de "meras suposições". A modulação foi, então, afastada por unanimidade pelo Tribunal.

Em linha semelhante, o argumento do aumento do número de demandas no Judiciário como causa suficiente para ensejar a modulação foi afastado no RE 680089:

O SENHOR MINISTRO MARCO AURÉLIO - A modulação, a essa altura, apenas causará problemas, implicações inúmeras.

O SENHOR MINISTRO LUIZ FUX - Eu não sei, eu tenho a impressão de que se nós formos claros e dissermos que a declaração de inconstitucionalidade, ela tem a sua validade a partir da liminar, respeitadas as ações em curso, resolvemos vários problemas, e evitamos inúmeros outros.

O SENHOR MINISTRO RICARDO LEWANDOWSKI (PRESIDENTE) - O advogado do Pará? Procurador? Vossa Excelência quer...

O SENHOR JOSÉ ALOÍSIO CAMPOS (PROCURADOR DO ESTADO DO PARÁ) - Só acrescentar que isso vai trazer uma multiplicidade de demandas, ainda essas que estão em curso vão progredir, e de forma multifacetada, em vinte Unidades da Federação.

O SENHOR MINISTRO RICARDO LEWANDOWSKI (PRESIDENTE) - Eu tenho a impressão que o Pará tem um bom corpo de procuradores e saberá dar conta dessas ações.

Ao contrário dos embargos acima, o ministro Lewandowski não questionou os efeitos que a decisão produziria no tocante à multiplicidade de demandas. Em sentido oposto, ele parece ter reconhecido, implicitamente, que a prognose levantada pelo Procurador do Estado pudesse de fato ocorrer. Assim, o argumento consequencialista foi rechaçado não por falta de evidência, mas com base na crença de que os procuradores paraenses teriam condições suficientes para "dar conta dessas ações". Essa afirmação é, no entanto, ela própria, de difícil comprovação, já que se refere à qualidade dos procuradores do Estado, o que, se levado a sério, demandaria dados mínimos que comprovassem o seu desempenho eficiente. Tais dados, no entanto, demandam a produção de um tipo de prova diverso daquele requerido para a comprovação de prognoses, já que dizem respeito a fatos passados e não à descrição de eventos futuros.

Se se pretende interpretar a afirmação do ministro de maneira mais branda, a questão que se coloca é por que no caso dos embargos haveria a necessidade de que a Fazenda Nacional comprovasse que os litígios não seriam fruto de meras intuições, enquanto no RE 680089 a afirmação do Procurador do Estado do Pará não é questionada por nenhum ministro presente no julgamento.

As incongruências ficam mais nítidas quando se comparam as posturas adotadas pelos ministros nos julgamentos acima com o posicionamento do ministro Luís Roberto Barroso na QO na ADI 4425, mesmo caso exposto na seção 3.1 deste trabalho.

Dentre os diversos argumentos do ministro para justificar a modulação, vê-se sua preocupação com a "renovação da litigiosidade independentemente da iniciativa das partes". Implícita nessa frase está a tentativa de reduzir o número de ações que, possivelmente, resultariam da decisão caso não se optasse pela modulação dos efeitos.

A inconsistência dos julgados reside no fato de que nos ED no RE 569056 o argumento de aumento de litígios é afastado por falta de provas; no RE 680089, o argumento é assumido como consequência provável da decisão, sendo, no entanto, afastado pela crença de que os procuradores saberiam lidar com essas demandas; e na QO na ADI 4425, o mesmo argumento consequencialista é apresentado pelo próprio ministro, sem qualquer prova, servindo de justificativa para a modulação. 
O problema reside no fato de que a mesma consequência (aumento de litígios) é abordada de forma totalmente diversa nos três casos, sem que haja qualquer segurança ao contribuínte de qual será o seu peso no resultado final da decisão. Além de colocar em xeque a noção de que as decisões decorrem do ordenamento jurídico e não constituem meras arbitrariedades do aplicador da lei, os julgamentos revelam a incapacidade dos ministros de lidar de forma uniforme com o mesmo tipo de argumentos consequencialistas em casos diversos, indicando uma limitação cognitiva para a justificação racional das decisões com base em consequências.

\subsubsection{Prognoses e cadeias de consequência sem provas}

A tese de deficit epistêmico também é corroborada por um segundo problema identificado a partir dos dados analisados, qual seja, os ministros elaboram prognoses ou criam cadeias de consequências sem que haja qualquer prova ou presunção legal indicando que sua ocorrência decorre da alternativa decisória adotada. Esse ponto é particularmente evidente no RE 405579, no qual o ministro Gilmar Mendes argumentou com base nas consequências das consequências que adviriam da declaração de nulidade ex tunc (A1 $\rightarrow$ C1 $\rightarrow[\ldots] \rightarrow$ Cn) e na ADI 875, na qual cada ministro pareceu se preocupar com uma consequência específica decorrente da concessão de um prazo maior de prolongamento dos efeitos da decisão. Veja-se cada um dos referidos julgados de forma mais detalhada.

No RE 405579, o Supremo Tribunal Federal teve que decidir se o benefício de 40\% de redução de alíquota do Imposto de Importação, concedido a empresas montadoras e fabricantes de veículos, poderia ser estendido, com base na isonomia, a uma empresa que, embora importasse pneus, não os produzia. A Fazenda Nacional teve o seu recurso, por maioria, julgado procedente, dentre outras justificativas porque não caberia ao STF "acrescentar exemplos à lei sob o argumento do princípio da isonomia" 59 .

O ministro Gilmar Mendes, embora vencido, defendia a extensão do benefício para preservar “os estímulos aos investimentos e à produção, pelo menos até que o legislador elabore novas regras para disciplinar a matéria" ${ }^{0}$. Segundo o ministro, se o entendimento da Fazenda Nacional prevalecesse, as montadoras e fabricantes de veículos teriam uma vantagem competitiva no mercado em relação aos seus concorrentes que não preenchessem os requisitos legais necessários para aferição do benefício fiscal.

De acordo com o ministro Gilmar Mendes, a declaração de nulidade ex tunc não seria a melhor solução para o caso, pois além de resultar na extirpação do benefício fiscal do ordenamento jurídico, desencadearia uma série de consequências negativas:

A declaração de nulidade total da referida expressão, com eficácia ex tunc, resultará, invariavelmente, em distorção do sistema do imposto de importação concebido para a produção de veículos e do estímulo pretendido à indústria automobilística.

Ademais, tal distorção repercute na oferta dos produtos no mercado de reposição, com impacto relevante no equilíbrio do mercado, no consumo interno e na inflação (cf. COOTER e ULEN. Law and Economics. $5^{\text {a }}$ ed. Boston: Pearson: 2007, p. 32 e ss.) ${ }^{61}$ (grifo nosso)

Antes de se avançar no argumento, é pertinente destacar que citação do manual de análise econômica de Cooter e Ulen no voto de Gilmar Mendes não apresenta nenhuma relação direta com o tema objeto de discussão no julgamento. As páginas citadas tratam, genericamente, do equilíbrio do mercado, abordando questões que vão desde o equilíbrio em indústrias perfeitamente competitivas até o equilíbrio em mercados monopolísticos e a capacidade de imposição de preço nesses últimos ${ }^{62}$.

59 STF, Tribunal Pleno, RE 405579, Rel. Min. Joaquim Barbosa, j. em 01/12/2010, DJe 03/08/2011.

60 Trecho do voto do ministro Gilmar Mendes. STF, Tribunal Pleno, RE 405579, Rel. Min. Joaquim Barbosa, j. em 01/12/2010, DJe $03 / 08 / 2011$.

61 Trecho do voto do ministro Gilmar Mendes. STF, Tribunal Pleno, RE 405579, Rel. Min. Joaquim Barbosa, j. em 01/12/2010, DJe 03/08/2011.

62 COOTER Robert; ULEN, Thomas. Law and Economics. 5. ed. Boston: Pearson: 2007. p. 32. 
O argumento consequencialista do ministro Gilmar Mendes pode ser descrito esquematicamente da seguinte forma:
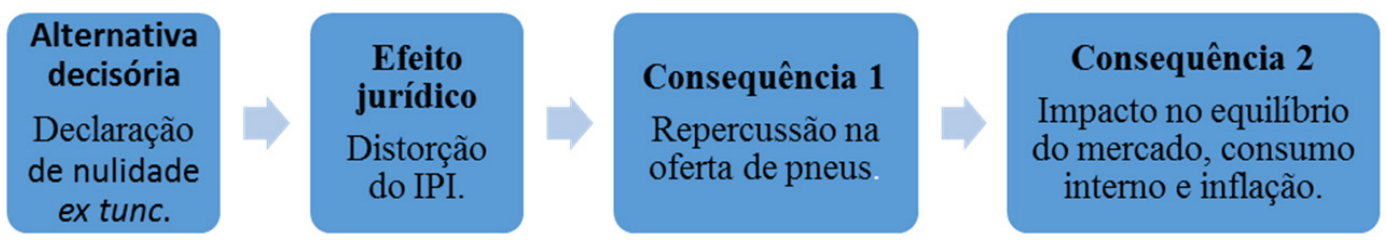

Mais uma vez, o problema da argumentação consequencialista foi a falta de evidências empíricas capazes de corroborar a tese de que necessariamente, da declaração de nulidade ex tunc, decorreriam todas as consequências elencadas pelo ministro. A questão é particularmente interessante porque Gilmar Mendes usa a expressão "resultará, invariavelmente" sem, no entanto, apresentar um dado sequer que confirme a ocorrência dos eventos, ou pelo menos, a alta probabilidade destes. Não há qualquer evidência que permita concluir que da declaração de nulidade ex tunc decorrerá um "impacto relevante no equilíbrio do mercado, no consumo interno e na inflação" "63. Se, de um lado, o ministro não tem como provar a cadeia de consequências, de outro, também faltam recursos aos demais ministros para provar a sua não ocorrência.

O perigo da elaboração de cadeias de consequências visando à defesa de uma alternativa decisória específica, como fez o ministro Gilmar Mendes, é, ao fim, um problema relativo à utilização do consequencialismo militante ${ }^{64}$, no qual, dada a proibição de non liquet (art. 126 do Código de Processo Civil), a autoridade judicante competente soluciona a controvérsia com base no seu subjetivismo. Nesses casos, o contribuinte é colocado, novamente, numa posição de dúvida quanto à existência de uma decisão racionalmente fundamentada, decorrente do ordenamento jurídico e não do decisionismo arbitrário daquele a quem incumbe resolver o conflito.

Passa-se agora à análise da ADI $875^{65}$. Nesse julgamento, discutiu-se a constitucionalidade de diversos dispositivos da Lei Complementar no 62/1989 relativos ao cálculo, entrega e controle de recursos dos Fundos de Participação dos Estados à luz do art. 161, II, da Constituição Federal de 1988. O dispositivo determina caber à lei complementar estabelecer normas sobre os critérios de rateio dos fundos, objetivando a promoção do equilíbrio socioeconômico entre Estados.

O Tribunal, por maioria, julgou a ADI procedente, por entender pela omissão estatal inconstitucional no tocante à elaboração de uma lei capaz de promover o equilíbrio socioeconômico entre os Estados. $\mathrm{O}$ STF, porém, optou pela modulação dos efeitos da declaração de inconstitucionalidade já que a "imediata supressão da ordem jurídica [da Lei Complementar no 62/1989] representaria incomensurável prejuízo ao interesse público e à economia dos Estados" ${ }^{\prime 6}$. Segundo o Tribunal, ainda que a Lei Complementar não estivesse cumprindo, adequadamente, o seu papel para a promoção do equilíbrio socioeconômico entre os Estados, a declaração de nulidade ex tunc resultaria em um vácuo legislativo que, comparativamente, efetivaria em menor medida a ordem constitucional, já que inexistiria qualquer critério para o repasse de recursos aos Estados.

Assim, a discussão que se colocou foi por quanto tempo a norma inconstitucional deveria continuar a produzir seus efeitos, de forma que fosse dado ao Congresso tempo suficiente para a elaboração de uma nova lei complementar capaz de cumprir com as exigências constitucionais. Para o ministro Cezar Peluso,

63 Trecho do voto do ministro Gilmar Mendes. STF, Tribunal Pleno, RE 405579, Rel. Min. Joaquim Barbosa, j. em 01/12/2010, DJe 03/08/2011.

64 SCHUARTZ, Luis Fernando. Consequencialismo jurídico, racionalidade decisória e malandragem. p. 31. Disponível em: < http://bibliotecadigital.fgv.br/dspace/bitstream /handle/10438/1724/CONSEQUENCIALISMO;jsessionid=1D7FD074152F03813EF80E 88526D7381sequence=1>. Acesso em: 7 set. 2015.

65 O STF conheceu a ação por entender pela fungiblidade entre as ações diretas de inconstitucionalidade por ação e por omissão. 66 Trecho do voto do ministro Gilmar Mendes, STF, Tribunal Pleno, ADI 875, Rel. Min. Gilmar Mendes, j. em 24/02/2010, DJe 29/04/2010. 
deveria ficar claro na decisão que, após o transcurso do prazo de 24 meses, a lei ficaria sem nenhum efeito, pois assim seria criada uma pressão política para a elaboração de uma nova lei complementar e, por outro lado, também se evitaria que fossem geradas consequências econômicas negativas para os Estados no curto prazo. O ministro Ricardo Lewandowski propôs a extensão do prazo para 36 meses $^{67}$ :

[...]. Não quero insistir nisso, mas entendo que é um ano eleitoral e esse ano está praticamente perdido em termos legislativos. Penso que seria de melhor alvitre que fixássemos o prazo de trinta e seis meses, até porque é uma matéria técnica, depende de estudos.

Tanto o ministro Peluso quanto o ministro Lewandowski defenderam o prazo no qual a norma inconstitucional deveria continuar a produzir seus efeitos com base em argumentos consequencialistas. Para o primeiro, um prazo menor exerceria pressão política sobre o Poder Legislativo, criando incentivos para a elaboração imediata de uma nova lei. Para Lewandowski, o prazo adequado seria de 36 meses, possibilitando a elaboração de estudos que pudessem determinar qual seria o percentual correto a que cada estado faria jus no novo regime de partilha dos recursos do Fundo de Participação dos Estados. Em que pese todas essas considerações, os efeitos da norma foram mantidos até 31 de dezembro de 2012, para não se "quebrar o ano fiscal". Assim, o prazo escolhido acabou sendo de 35 meses contados da data do julgamento no STF.

A argumentação do ministro Peluso não era, necessariamente, incompatível com a do ministro Lewandowski. Assim como o prazo de 24 meses talvez pudesse ter incentivado o Legislativo a apresentar uma resposta mais ágil à decisão do STF, a demora para elaboração da nova lei complementar ${ }^{68}$ e o fato de ela ser hoje alvo de questionamento no controle concentrado talvez indiquem a dificuldade de fixação de novos critérios para a distribuição de recursos entre os Estados e a necessidade de que a decisão do Tribunal tivesse de fato se preocupado com a concessão de um prazo suficiente que permitisse ao Legislativo elaborar novos estudos técnicos. Dessa forma, o que se pretende deixar claro não é a divergência entre os ministros, mas sim o fato de que ambos criaram prognoses sem qualquer evidência que as sustentasse: da redução do prazo poderia não decorrer uma resposta mais ágil, do mesmo modo como da sua extensão não resultaria necessariamente a elaboração de novos estudos — talvez estes pudessem ser feitos em tempo inferior ou ainda demandassem mais de 36 meses.

Esse caso evidencia problemas de incerteza ${ }^{69}$ e de racionalidade limitada ${ }^{70}$ que afetam os ministros e que, por causa disso, talvez, indiquem que o uso de argumentos consequencialistas deveria ser evitado na tomada de decisão. Em relação aos problemas de incerteza, é difícil ou praticamente impossível demonstrar a tempo e custos razoáveis a responsividade do Legislativo à decisão do Judiciário, avaliando-se hipotética e comparativamente a qualidade da norma elaborada no caso de concessão do prazo de 24 meses em relação à de 36 meses. Inclusive, poder-se-ia falar mesmo na impossibilidade de determinação da probabilidade de ocorrência da resposta do Legislativo, já que as interações entre os Poderes tendem a ser complexas e com-

67 O ministro Joaquim Barbosa sugeriu a prorrogação dos efeitos da norma pelo prazo de 30 meses sem, no entanto, apresentar quais seriam os ganhos de se fazer essa opção. Sua argumentação focava no fato de que por se tratar de ano eleitoral, "nada mais acontecer[ia] nessa seara".

68 A nova lei complementar (Lei Complementar no 143/2013) somente foi editada em 18 de julho de 2013, quase 7 meses após o decurso do prazo fixado pelo Supremo Tribunal Federal. Em 25 de novembro de 2013, porém, ela se tornou objeto da ADI 5069 no Supremo Tribunal Federal, sob o fundamento de que haveria apenas estendido, até o fim de 2015, a vigência dos coeficientes individuais declarados inconstitucionais pelo STF e os transformando em piso para repasses a partir do ano de 2016. CORREIA NETO, Celso de Barros. Supremo julgará novamente os critérios de partilha do FPE. Revista Consultor Jurídico, 15 mar. 2014 . Disponível em: <http://www.conjur.com.br/2014-mar-15/observatorio-constitucional-stf-julgara novamente-criterios-partilha-fpe>. Acesso em: 26 nov. 2015.

69 Em casos de incerteza não se tem informações suficientes para determinação da probabilidade de a consequência de fato se materializar. VERMEULE, Adrian. Judging under uncertainty: An Institutional Theory of Legal Interpretation. Massachussetts: Harvard University Press, 2006. p. 171.

70 Racionalidade limitada é entendida em sentido lato, dizendo respeito à capacidade limitada de agentes reais entenderem e processarem informações. VERMEULE, Adrian. Judging under uncertainty: An Institutional Theory of Legal Interpretation. Massachussetts: Harvard University Press, 2006. p. 155. 
postas por variáveis inúmeras e de difícil averiguação ${ }^{71}$.

Quanto aos problemas de racionalidade limitada, o caso evidencia as limitações cognitivas dos ministros, uma vez que eles buscaram reduzir a uma única consequência (responsividade do Legislativo ou elaboração de estudos) todos os possíveis efeitos de sua decisão. Isto ressalta a incapacidade de os ministros processarem variáveis interrelacionadas - seria possível, por exemplo, imaginar a elaboração de uma argumentação consequencialista preocupada simultaneamente com a qualidade da norma elaborada com base em estudos técnicos e com o tempo de reação do Legislativo à decisão do Supremo Tribunal Federal.

O perigo da elaboração de prognoses sem qualquer estudo ou evidência capaz de lhes servir de suporte num cenário de incerteza e no qual os ministros apresentam racionalidade limitada para lidar com esse tipo de argumentação conduz, assim como a questão da elaboração de cadeias de consequências descrita acima, à utilização do consequencialismo militante. O problema reside nos enormes riscos da transformação da decisão dos ministros em um decisionismo arbitrário dada a impossibilidade de se comprovar a ocorrência das consequências respectivas à cada alternativa decisória.

\section{Considerações finais}

Com base no exposto, tem-se que a argumentação consequencialista realizada pelos ministros do Supremo Tribunal Federal para modular os efeitos da declaração de inconstitucionalidade em julgamentos de direito tributário pode ser considerada problemática por duas razões distintas A primeira delas é relativa a uma limitação necessária da argumentação preocupada com os efeitos práticos da decisão. Ela diz respeito à incerteza inerente à atribuição de consequências para cada alternativa decisória e à limitação racional dos ministros para trabalharem com diversas variáveis bem como analisarem provas complexas. A segunda limitação é contingente e é evidenciada pelos dados empíricos coletados. Trata-se do fato de que os juízos de prognose realizados pelos ministros não são acompanhados de estudos que demonstrem a sua ocorrência. Essas duas limitações, talvez, indiquem que a melhor postura a ser adotada pelos ministros é, em relação às provas $^{72}$ e estudos apresentados pela parte, uma de deferência, enquanto, em relação à sua própria argumentação, uma que procure evitar o uso de consequências não demonstradas ao longo do processo ${ }^{73}$.

Se inexiste evidência demonstrando que os ministros têm capacidades epistêmicas melhores do que a de um indivíduo qualquer para atribuir probabilidades a eventos que podem ou não ocorrer no futuro ${ }^{74}$,

71 VERMEULE, Adrian. Judging under uncertainty: An Institutional Theory of Legal Interpretation. Massachussetts: Harvard University Press, 2006. p.154-155.

72 O tema de provas é complexo. No nível mais abstrato da discussão, dado que as prognoses devem decorrer da alternativa decisória, é possível discutir até que ponto os ministros deveriam basear sua decisão na probabilidade do evento se materializar (e.g., uma prognose cuja chance de ocorrência é de 1\% deveria ser igualmente relevante para a resolução do caso como uma cuja chance de ocorrência é de 99\%?). Essa escolha pode depender de uma valoração moral (PECZENIK, Aleksander. On Law and Reason. Preface by Jaap C. Hage. Law and Philosophy Library, Sweden: Springer, v. 8, p. 20, 2008) que talvez devesse ser feita por representantes eleitos e não por juízes. É possível se defender, ademais, que o uso de provas deveria atender aos objetivos e propósitos do direito, de forma tal que mesmo as provas não necessariamente boas em termos científicos poderiam ser aceitas no direito. (SCHAUER, Frederick. Can Bad Science Be Good Evidence: Lie Detection, Neuroscience, and the Mistaken Conflation of Legal and Scientific Norms. Cornell Law Review, Virginia Public Law and Legal Theory Research Paper, n. 14, ago. 2009. Disponível em: < http://ssrn. $\mathrm{com} /$ abstract $=1448744>$. Acesso em: 30 nov. 2015). Para a defesa de uma abordagem das provas no direito em certa medida indiferente à problematização científica, ver SCHUARTZ, Luis Fernando. Interdisciplinariedade e Adjudicação: Caminhos e Descaminhos da Ciência no Direito. Disponível em: < http://bibliotecadigital.fgv.br/dspace/bitstream/handle /10438/2174/TpD\%20008\%20 $\% 20$ Schuartz $\% 20 \% 20$ Interdisciplinaridade $\% 20$ e\%20adjudica \%C3\%A7\%C3\%A3o.pdf?sequence=1>. Acesso em: 30 nov. 2015.

73 Também poderia se permitir o uso de consequências pelos ministros, ainda que não provadas no processo, quando o próprio ordenamento jurídico, através do estabelecimento de uma presunção, tomasse como verdadeira a ocorrência da prognose. Nesses casos, o ônus da prova seria invertido, cabendo àquele que pretende afastar a presunção provar a não ocorrência da prognose (VERMEULE, Adrian. Judging under uncertainty: An Institutional Theory of Legal Interpretation. Massachussetts: Harvard University Press, 2006. p.170).

74 VERMEULE, Adrian. Rationally Arbitrary Decisions (in Administrative Law). Harvard Public Law Working Paper, Harvard Law 
então a adoção de uma postura deferente aos dados e estudos apresentados pelas partes, talvez, seja a mais adequada se o que se pretende é evitar o decisionismo arbitrário do intérprete. Isto porque, dessa forma, a atribuição de consequências às alternativas decisórias não será fruto de meras intuições dos ministros, mas resultado de trabalhos elaborados por pessoas que supostamente tem a capacidade de avaliar os efeitos da decisão e, portanto, tem melhores condições de fazer as prognoses. Nesse sentido, no julgamento do RE 559937, por exemplo, o ministro Dias Toffoli agiu de maneira adequada ao determinar que a questão da modulação deveria ser discutida com base em dados concretos, em sede de embargos de declaração, ante a falta de elementos para a sua avaliação durante o julgamento do recurso extraordinário.

Caso as partes não apresentem qualquer evidência demonstrando a possibilidade de ocorrência de uma consequência e, ainda assim, o ministro pretenda se valer desta na sua argumentação, poderia ele convocar um perito ou uma comissão de peritos, cujo fim seria precisamente comprovar os efeitos da decisão ${ }^{75}$. A hipótese não é absurda, havendo previsão no art. $9^{\circ}$, $\$ 1^{\circ}$, da Lei 9.868/1999.

Por fim, nos casos em que, ao final do processo, não se verifica a existência de qualquer evidência capaz de demonstrar que a prognose pode decorrer da decisão do ministro, o uso de argumentos consequencialistas deveria ser evitado como justificativa para a modulação dos efeitos da declaração de inconstitucionalidade em julgamentos de direito tributário. Isso porque, ainda que seja verdade que "a maioria significativa dos casos será resolvida sob condições (mais ou menos radicais) de subdeterminação jurídica"76 , daí não se segue a possibilidade de concessão de ampla margem de discricionariedade aos ministros para que eles imaginem e especulem acerca de todos os possíveis efeitos da sua decisão. Admitir isto seria permitir que, em cenários de incerteza e de limitações cognitivas dos agentes, os julgamentos pudessem ser resolvidos de forma arbitrária, colocando-se não apenas o contribuinte, mas também a Fazenda, em uma posição de dúvida quanto a quais são as regras que realmente guiam o processo de tomada de decisão.

O problema se tornaria ainda mais grave se os ministros, a pretexto de evitarem resultados absurdos advindos da sua decisão, se vissem na obrigação de adotar uma solução capaz de "corrigir" esses efeitos negativos $^{77}$. Nesses casos, é possível pensar que, na ausência de qualquer evidência para sustentar a elaboração das prognoses, ter-se-ia a prevalência de meras opiniões dos ministros as quais poderiam, ao final, produzir consequências mais danosas do que aquelas que se buscou primeiramente evitar ${ }^{78}$. Assim, há fortes argumentos para se evitar o uso do consequencialismo judicial quando as prognoses não são confirmadas até o final do processo ${ }^{79}$.

\section{REFERÊNCIAS}

AARNIO, Aulis. Essays on the Doctrinal Study of Law. Heidelberg: Springer, 2011.

School, n. 13-24, p. 4, mar. 2013. Disponível em: <http://ssrn.com/abstract=2239155>. Acesso em: 30 nov. 2015.

75 Não se ignoram os custos que a convocação de perito ou da comissão de peritos poderia gerar para o processo. A título meramente exemplificativo tem-se, além dos custos de transação para a escolha e contratação dos peritos, os custos relacionados ao aumento do tempo necessário para a resolução do caso. Sobre a aplicação desse dispositivo para lidar com problemas de antecipação de efeitos decisórios no julgamento dos chamados "planos econômicos", v. LEAL, Fernando. Os impactos dos planos econômicos e a encruzilhada do Supremo. Disponível em: <https://jota.info/colunas/supra/os-impactos-dos-planos-economicos-e-encruzilhadasupremo-15082016>. Acesso em: 24 maio 2017.

76 FALCÃO NETO, Joaquim; SCHUARTZ, Luís Fernando; ARGUELHES, Diego Werneck. Jurisdição, Incerteza e Estado de Direito. Revista de Direito Administrativo, v. 243, p. 97, 2006.

77 SUNSTEIN, Cass S.; VERMEULE, Adrian. Interpretation and Institutions. Michigan Law Review, v. 101, n. 04, p. $915,2003$.

78 SUNSTEIN, Cass S.; VERMEULE, Adrian. Interpretation and Institutions. Michigan Law Review, v. 101, n. 04, p. $915,2003$.

79 O presente trabalho não lida com mecanismos que poderiam reduzir os custos associados a uma tomada de decisão num cenário de incerteza e risco. Sobre o tema, ver VERMEULE, Adrian. Rationally Arbitrary Decisions (in Administrative Law). Harvard Public Law Working Paper, Harvard Law School, n. 13-24, mar. 2013. Disponível em: <http://ssrn.com/abstract=2239155>. Acesso em: 30 nov. 2015. 
AARNIO, Aulis. Introduction. In: PECZENIK, Aleksander. On Law and Reason. Preface by Jaap C. Hage. Law and Philosophy Library, Sweden: Springer, v. 8, 2008.

ADEODATO. João Maurício. Bases para uma metodologia da pesquisa em direito. Revista CEJ, Brasília: Conselho da Justiça Federal, Centro de Estudos Judiciários, v. 7, 1998.

ARGUELHES, Diego Werneck. Argumentação Consequencialista e Estado de Direito: Subsídios para uma compatibilização. In: XIV Encontro Nacional do CONPEDI, 2005, Fortaleza. Anais do XIV Encontro Nacional do CONPEDI. Florianópolis: Fundação Boiteaux, 2005.

ARGUELHES, Diego; LEAL, Fernando. Pragmatismo como [Meta] Teoria Normativa da Decisão Judicial: Caracterização, Estratégias e Implicações. In: SARMENTO, Daniel Antonio de Moraes (Org.). Filosofia e Teoria Constitucional Contemporânea. Rio de Janeiro: Lumen Juris, 2009.

ÁVILA, Ana Paula. A modulação de Efeitos Temporais pelo STF no Controle de Constitucionalidade. Porto Alegre: Livraria do Advogado Editora, 2009.

ÁVILA, Humberto. A justificação das decisões judiciais. In: Seminário Teoria da Decisão Judicial, 23, 24 e 25 de abril de 2014, Brasília, DF. Conselho da Justiça Federal, Centro de Estudos Judiciários, Coordenação Científica: Ricardo Villas-Bôas Cueva. Brasília: CJF, 2014. Disponível em: <http://www.cjf.jus.br/CEJ-Coedi/serie-cadernos/serie-caderno-30 >. Acesso em: 27 set. 2015.

ÁVILA, Humberto. Argumentação Jurídica e a Imunidade do Livro Eletrônico. Revista Eletrônica de Direito do Estado, Salvador: Instituto Brasileiro de Direito Público, n. 21, jan./fev./mar. 2010.

ÁVILA, Humberto. Sistema Constitucional Tributário. 5. ed. São Paulo: Saraiva, 2012.

ÁVILA, Humberto. Teoria da Segurança Jurídica. 3. ed. São Paulo: Malheiros, 2014.

ÁVILA, Humberto. Teoria dos Princípio: Da definição à aplicação dos princípios jurídicos. 16. ed. São Paulo: Malheiros Editores, 2015.

BARROSO, Luís Roberto. O controle de constitucionalidade no direito brasileiro: exposição sistemática da doutrina e análise crítica da jurisprudência. 3. ed. São Paulo: Saraiva, 2008.

BECKER, Alfredo Augusto. Teoria Geral do Direito Tributário. 4. ed. São Paulo: Noeses, 2007.

CARVALHO, Paulo de Barros. Direito tributário: linguagem e método. 4. ed. São Paulo: Noeses, 2011.

COOTER Robert; ULEN, Thomas. Law and Economics. 5. ed. Boston: Pearson: 2007.

CORREIA NETO, Celso de Barros. Supremo julgará novamente os critérios de partilha do FPE. Revista Consultor Jurídico, 15 mar. 2014. Disponível em: <http://www.conjur.com.br/2014-mar-15/observatorioconstitucional-stf-julgara novamente-criterios-partilha-fpe>. Acesso em: 26 nov. 2015.

DERZI, Misabel Abreu Machado. Modificações da jurisprudência: proteção da confiança, boa-fé objetiva e irretroatividade como limitações constitucionais ao poder judicial de tributar. São Paulo: Noeses, 2009.

FALCÃO NETO, Joaquim; SCHUARTZ, Luís Fernando; ARGUELHES, Diego Werneck. Jurisdição, Incerteza e Estado de Direito. Revista de Direito Administrativo, v. 243, 2006.

GRAETZ, Michael J.; SCHENK, Deborah. Federal Income Taxation: principles and Policies. 7. ed. St. Paul: Foundation Press, 2013.

HART, H. L. A. The concept of law. 2. ed. Oxford: Oxford University Press, 1994.

HOLMES, Oliver; BURTON David. Progressive Masks: Letters of Oliver Wendell Holmes, Jr., and Franklin Ford. Newark: University of Delaware Press, 1982.

LEAL, Fernando. Os impactos dos planos econômicos e a encruzilhada do Supremo. Disponível em: < https:// 
jota.info/colunas/supra/os-impactos-dos-planos-economicos-e-encruzilhada-supremo-15082016>. Acesso em: 24 maio 2017.

LEAL, Fernando. Ziele und Autorität: Zu den Grenzen teleologischen Rechtsdenkens. Baden-Baden: Nomos, 2014.

LIPSEY, R. G.; LANCASTER, Kelvin. The General Theory of Second Best. The Review of Economic Studies, v. 24, n. 01, 1956-1957.

LUHMANN, Niklas. Selbstreferenz und Teleologie in gesellschaftstheoretischer Perspektive. Nene Hefte für Philosophie, Göttingen, v. 20, 1981.

LUHMANN, Niklas. Sistema Jurídico y Dogmática Jurídica. Madrid: Centro de Estudios Constitucionales, 1983.

MACCORMICK, Neil. Legal Reasoning and Legal Theory: Clarendon Law Series. Oxford: Oxford University Press, 1978.

MACCORMICK, Neil. On Legal Decisions and their Consequences: from Dewey to Dworkin. New York University Law Review, v. 58, n. 2, maio 1983.

MACCORMICK, Neil. Rhethoric and the Rule of Law: A Theory of Legal Reasoning (Law, State and Practical Reason). Oxford: Oxford University Press, 2005.

MELLO, Celso Antônio Bandeira de. Curso de Direito Administrativo. 29. ed. São Paulo: Malheiros Editores, 2012.

OLIVEIRA, Fabiana Luci de (Org). Justiça em foco: estudos empíricos. Rio de Janeiro: Editora FGV, 2012.

OLIVEIRA, Luciano. Não fale do Código de Hamurábi! Anuário dos Cursos de Pós-Graduação em Direito (UFPE), v. 13, 2003. Disponível em: <https://www.uniceub.br/media /180293/Texto_IX.pdf>. Acesso em: 4 nov. 2015.

ORDEM DOS ADVOGADOS DO BRASIL. Disponível em: < http://www.oab.org.br/noticia/20734/ brasil-sozinho-tem-mais-faculdades-de-direito-que-todos-os-pai ses>. Acesso em: 4 nov. 2015.

PARGENDLER, Mariana; SALAMA, Bruno Meyerhof. Direito e Consequência no Brasil: em busca de um discurso sobre o método. Revista de Direito Administrativo (RDA), Rio de Janeiro, v. 262, jan./abr. 2013.

PECZENIK, Aleksander. On Law and Reason. Preface by Jaap C. Hage. Law and Philosophy Library, Sweden: Springer, v. 8, 2008.

PISCITELLI, Tathiane dos Santos. Argumentando pelas consequências no direito tributário. São Paulo: Noeses, 2011.

POSCHER, Ralf. The Principles Theory. How many theories and what is their merit? In: KLATT, Matthias. Institutionalizing Reason: Perspectives on the Legal Philosophy of Robert Alexy. New York: Oxford University Press, 2009.

SANTI, Eurico Marcos Diniz de. A Modulação no Controle de Constitucionalidade de Novos Tributos. Revista Consultor Jurídico, 10 jul. 2014. Disponível em: < http://www.conjur.com.br/2014-jul-10/eurico-santimodulacao-supremo-criacao-tributo>. Acesso em: 18 set. 2015.

SCHAUER, Frederick. Can Bad Science Be Good Evidence: Lie Detection, Neuroscience, and the Mistaken Conflation of Legal and Scientific Norms. Cornell Law Review, Virginia Public Law and Legal Theory Research Paper, n. 14, ago. 2009. Disponível em: <http://ssrn.com/abstract=1448744>. Acesso em: 30 nov. 2015.

SCHOUERI, Luís Eduardo. Direito Tributário. 4. ed. São Paulo: Saraiva, 2014.

SCHUARTZ, Luis Fernando. Consequencialismo jurídico, racionalidade decisória e malandragem. Disponível em: 
< http://bibliotecadigital.fgv.br/dspace/bitstream /handle/10438/1724/CONSEQUENCIALISMO;jsess ionid=1D7FD074152F03813EF80E88526D7381sequence=1>. Acesso em: 7 set. 2015.

SCHUARTZ, Luis Fernando. Interdisciplinariedade e Adjudicaşão: Caminhos e Descaminhos da Ciência no Direito. Disponível em: <http://bibliotecadigital.fgv.br/dspace/bitstream/handle /10438/2174/ TpD $\% 20008 \% 20 \% 20$ Schuartz $\% 20 \% 20$ Interdisciplinaridade $\% 20 \mathrm{e} \% 20$ adjudica $\%$ C3\%A7\%C3\%A3o. pdf? sequence $=1>$. Acesso em: 30 nov. 2015.

SILVA, José Afonso da. Curso de Direito Constitucional Positivo. 35. Ed. São Paulo: Malheiros Editores, 2012.

SUNSTEIN, Cass R.; ULLMANN-MARGALIT. Second-order decisions. John M. Olin Program in Law and Economics Working Paper, n. 57, 1998.

SUNSTEIN, Cass S.; VERMEULE, Adrian. Interpretation and Institutions. Michigan Law Review, v. 101, n. 04 , p. 915, 2003.

SUNSTEIN, Cass S; VERMEULE, Adrian. Interpretation and Institutions. Michigan Law Review, v. 101, n. 04, 2003.

VERMEULE, Adrian. Judging under uncertainty: An Institutional Theory of Legal Interpretation. Massachussetts: Harvard University Press, 2006.

VERMEULE, Adrian. Rationally Arbitrary Decisions (in Administrative Law). Harvard Public Law Working Paper, Harvard Law School, n. 13-24, mar. 2013. Disponível em: < http://ssrn.com/abstract=2239155>. Acesso em: 30 nov. 2015.

VERMEULE, Adrian. Three Strategies of Interpretation. San Diego Law Review, n. 42, p. 607-628, 2005.

VIEIRA, Oscar Vilhena. Supremocracia. Revista Direito GV, São Paulo, n. 8, p. 441-464, jul./dez. 2008. 
Para publicar na revista Brasileira de Políticas Públicas, acesse o endereço eletrônico www.rbpp.uniceub.br

Observe as normas de publicação, para facilitar e agilizar o trabalho de edição. 